\title{
Intensive Pedestrain Survey of Three Tracts to be Impacted by the Planned Expansion of the San Antonio International Airport, Bexar County, Texas
}

Antonia L. Figueroa

Center for Archeological Research, University of Texas at San Antonio

Jennifer L. Thompson

Follow this and additional works at: https://scholarworks.sfasu.edu/ita

Part of the American Material Culture Commons, Archaeological Anthropology Commons, Environmental Studies Commons, Other American Studies Commons, Other Arts and Humanities Commons, Other History of Art, Architecture, and Archaeology Commons, and the United States History Commons

Tell us how this article helped you.

This Article is brought to you for free and open access by the Center for Regional Heritage Research at SFA ScholarWorks. It has been accepted for inclusion in Index of Texas Archaeology: Open Access Gray Literature from the Lone Star State by an authorized editor of SFA ScholarWorks. For more information, please contact cdsscholarworks@sfasu.edu. 
Intensive Pedestrain Survey of Three Tracts to be Impacted by the Planned Expansion of the San Antonio International Airport, Bexar County, Texas

\section{Creative Commons License}

(c) (1) (8)

This work is licensed under a Creative Commons Attribution-NonCommercial 4.0 International License 

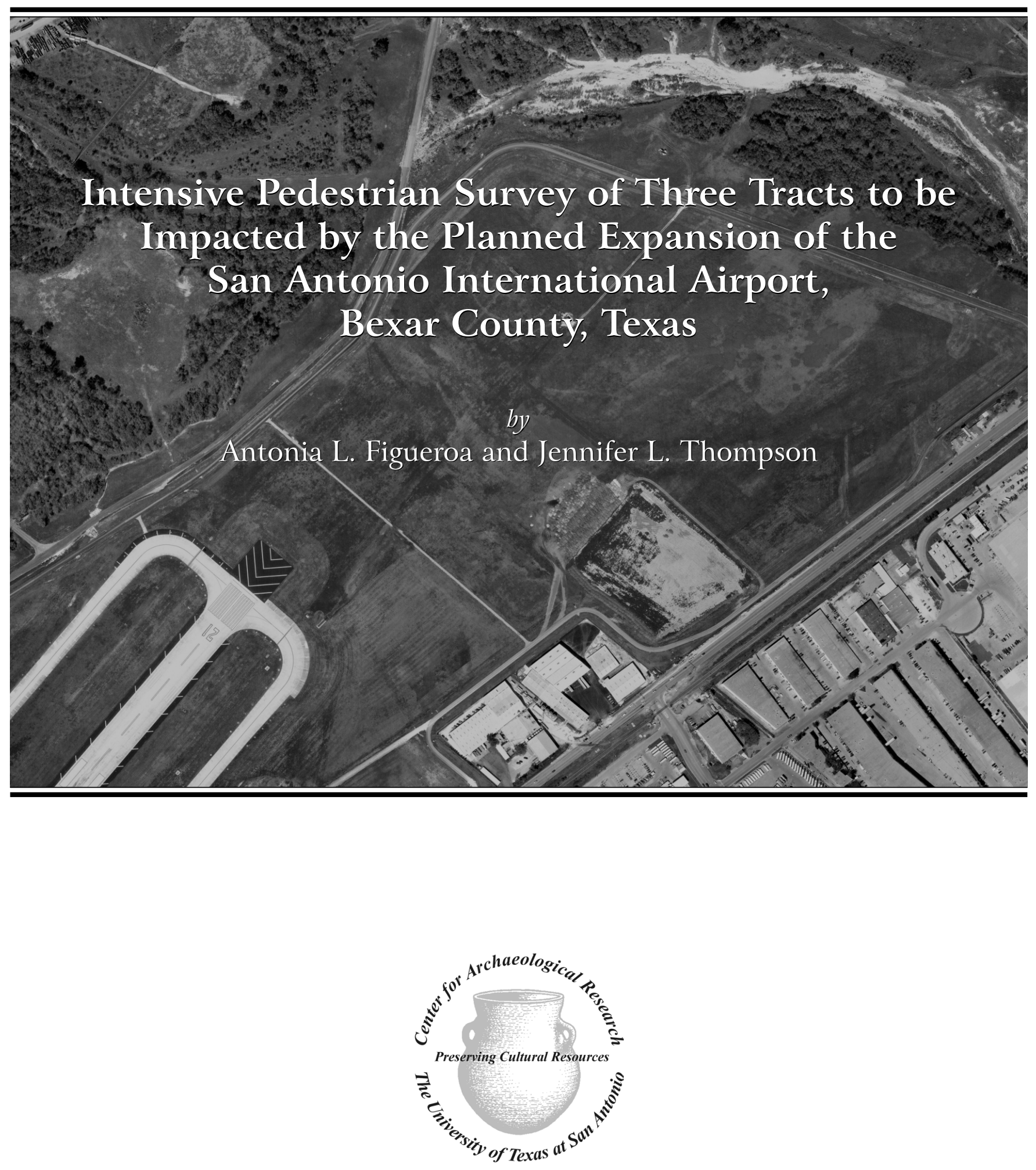

Center for Archaeological Research

The University of Texas at San Antonio

Archaeological Report, No. 357

2005 


\title{
Intensive Pedestrian Survey of Three Tracts to be Impacted by the Planned Expansion of the San Antonio International Airport, Bexar County, Texas
}

\author{
by \\ Antonia L. Figueroa and Jennifer L. Thompson
}

Steve A. Tomka

Principal Investigator

Texas Antiquities Permit No. 3619

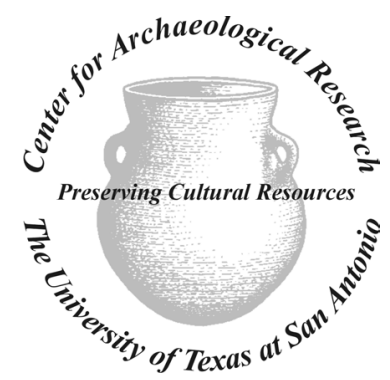

Archaeological Report, No. 357 (c) 2005

Prepared for:

Adams Environmental, Inc. San Antonio, Texas
Prepared by:

Center for Archaeological Research The University of Texas at San Antonio 
A list of publications offered by the Center for Archaeological Research is available. Call (210) 458-4378; write to the Center for Archaeological Research, The University of Texas at San Antonio, 6900 N. Loop 1604 W., San Antonio, Texas 78249-0658; e-mail to car@utsa.edu; or visit CAR’s web site at http://car.utsa.edu. 


\section{Abstract:}

During the months of March and April 2005, the Center for Archaeological Research (CAR) of The University of Texas at San Antonio conducted a 100 percent intensive pedestrian survey of three tracts of land (totaling 210 acres) for Adams Environmental, Inc. The project area is located within the boundaries of the San Antonio International Airport and the tracts are owned by the City of San Antonio Department of Aviation. The tracts represent the planned locations for the expansion of two runways and land development adjacent to them. The goal of the archaeological survey was to identify and document all prehistoric and/or historic archaeological sites in the project area. The archaeological survey revealed that there were major disturbances in all three tracts. No prehistoric and/or historic sites were encountered and no additional archaeological work is recommended in association with the runway expansion project.

The possibility that an alternative Widely Spaced Runway Option would be pursued for airport expansion was also considered as part of this project. The area that would be impacted by this alternative option is located on the northdescending bank of Salado Creek. Additional archaeological work, in the form of a 100 percent intensive pedestrian survey coupled with a standing structure survey, is recommended within this alternative area if this is the final option chosen for development.

All artifacts collected during these investigations are curated at the CAR facility according to Texas Historical Commission guidelines. These investigations were conducted under Texas Antiquities Permit No. 3619, with Dr. Steve Tomka, CAR director, serving as Principal Investigator. 


\section{Table of Contents:}

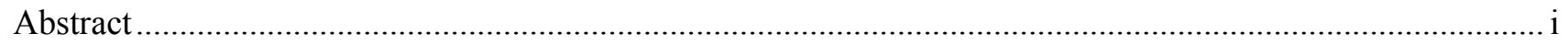

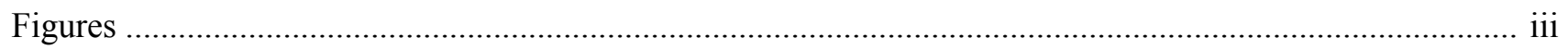

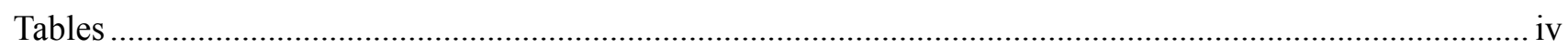

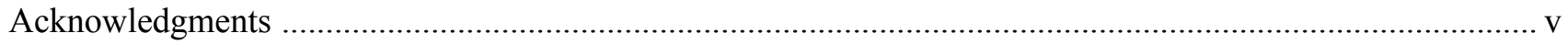

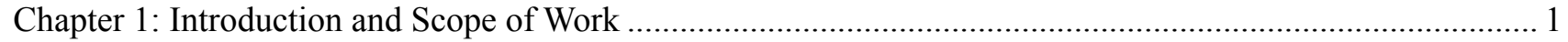

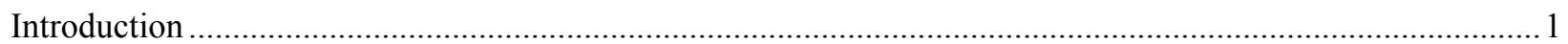

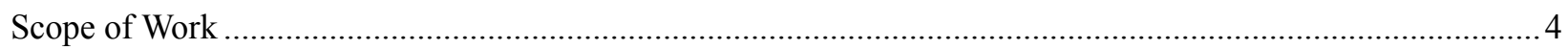

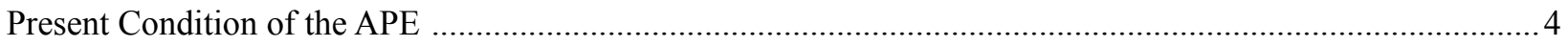

Chapter 2: Environmental Setting and Previous Archaeological Investigations ............................................ 9

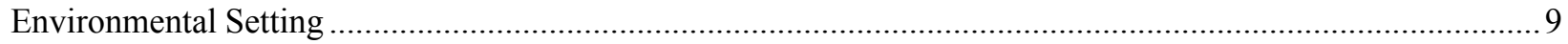

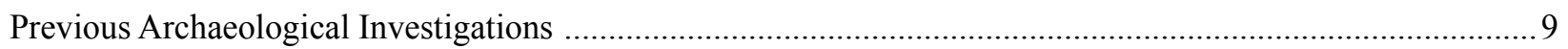

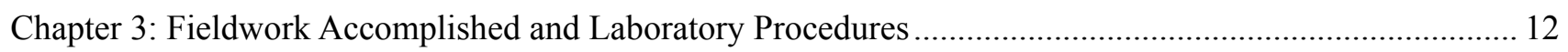

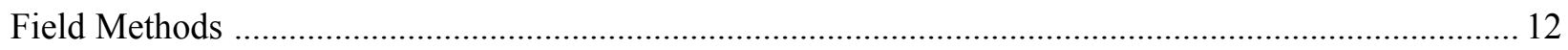

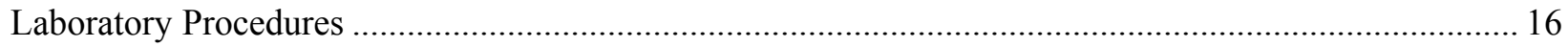

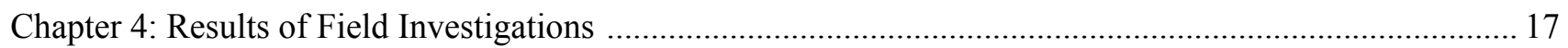

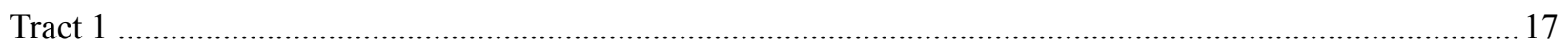

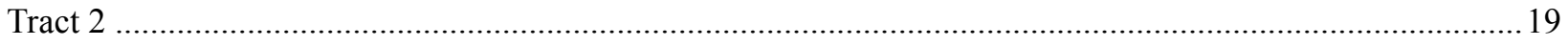

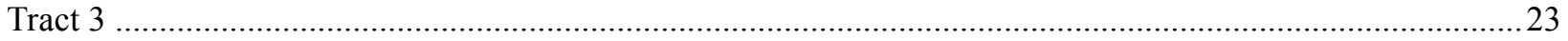

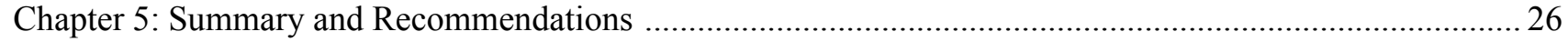

Cultural Resources Assessment of the Widely Spaced Runway Options ................................................ 27

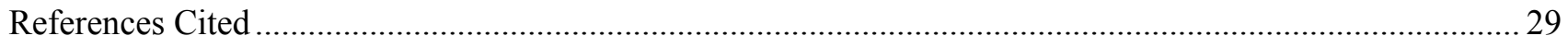

Appendix A: Intensive Pedestrian Survey of the Western Section of Tract 3 and Revisit of Site 41BX959 .... 32 


\section{Figures:}

Figure 1-1. Location of the project area in north-central Bexar County, Texas. .................................................. 1

Figure 1-2. Project area on the 1992 Longhorn, Texas, USGS quadrangle map..................................................2

Figure 1-3. Aerial photograph showing the entire project area. .....................................................................

Figure 1-4. Aerial photograph showing the eastern portion of the project area, Tracts 2 and 3. ...........................5

Figure 1-5. Aerial photograph showing the western portion of project area, Tract 1 . ......................................... 6

Figure 1-6. Clearance and grading within the north-central portion of Tract 2. .................................................. 7

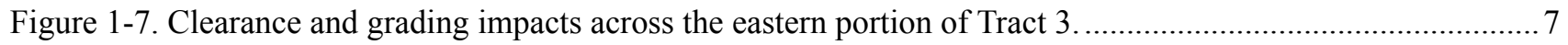

Figure 1-8. The survey tracts depicted on the 1953 Longhorn, Texas, 7.5' USGS topographic quadrangle. ..............8

Figure 3-1. Locations of shovel tests excavated in Tract 1. Note old road system superimposed from 1953

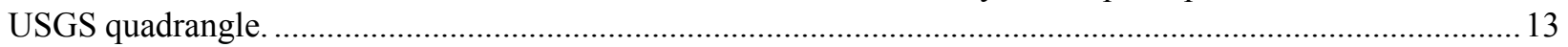

Figure 3-2. Locations of shovel tests and backhoe trenches excavated in Tract 2. ............................................ 14

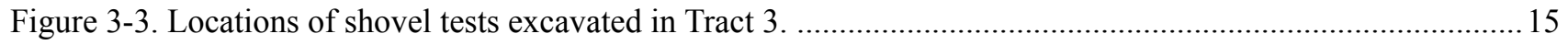

Figure 4-1. Tract 1, area adjacent to runway (runway to the right).................................................................... 18

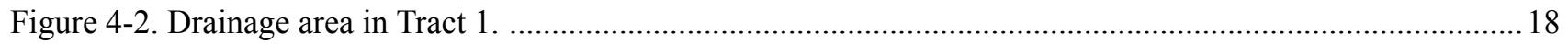

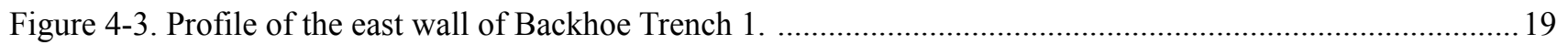

Figure 4-4. Landfill material encountered in Backhoe Trench 2. ..................................................................... 20

Figure 4-5. Debris on the south bank of Salado Creek in Tract 2. ...................................................................20

Figure 4-6. Profile of the east wall of Backhoe Trench 3. ................................................................................. 21

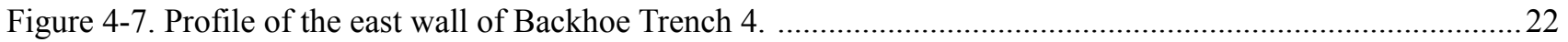

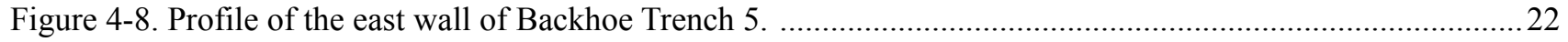

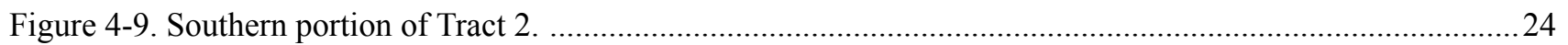

Figure 4-10. Paved roadway that crosses the southern portion of Tract 2. ........................................................2 24

Figure 5-1. Boundary of the area of impact for the Widely Spaced Runway Option...........................................22

Figure A-1. Original and new boundaries for site 41BX959. Not included in this report. 


\section{Tables:}

Table 4-1. Terminal Depths of Shovel Tests Excavated in Tract 1 ................................................................... 17

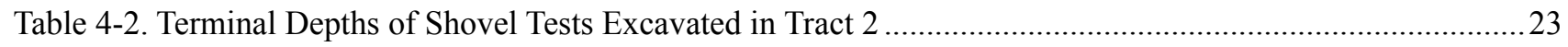

Table 4-3. Artifacts Recovered from Shovel Tests in Tract 2 ….........................................................................2 23

Table 4-4. Terminal Depths of Shovel Tests Excavated in Tract 3 (eastern section) .............................................25

Table A-1. Terminal Depths of Shovel Tests Excavated in the Western Section of Tract 3 .................................33

Table A-2. Artifacts Recovered from Shovel Tests in the Western Section of Tract 3 ...........................................34 


\section{Acknowledgments:}

The authors would like to thank Lynn Kitchen and Brian Gottschalk of Adams Environmental, Inc. for their assistance throughout the project. The authors would also like to thank Mr. Kao Lin Chen from the Planning and Engineering Office at the San Antonio International Airport for escorting the field crew during the archaeological investigations. Dr. Steve Tomka served as principal investigator on the project. Antonia Figueroa served as the project archaeologist and the field crew consisted of Claudia Branton, Lynn Eschenbaum, Leonard Kemp, and Bruce Moses. Richard Young and Bruce Moses prepared the graphics for the project and the final report was edited and formatted by Johanna Hunziker. Many thanks to all involved in the project. 



\section{Chapter 1: Introduction and Scope of Work}

\section{Introduction}

In January 2005, Adams Environmental, Inc. contracted the Center for Archaeological Research (CAR) of The University of Texas at San Antonio to conduct archaeological investigations in the form of a 100 percent intensive pedestrian survey associated with the expansion of two runways at the San Antonio International Airport and the development of a tract of land north of the airport (Figure 1-1). This document summarizes the results of the fieldwork and provides recommendations related to the proposed expansion and development project. Following this Introduction, this chapter also presents the scope of work and describes the condition of the project area prior to the survey. Chapter 2 briefly outlines the environmental setting of the project area and summarizes the previous archaeological research conducted in its vicinity. Chapter 3 discusses the field and laboratory methods employed during the project. Chapter 4 details the results of the pedestrian survey of the Area of Potential Effect and the last chapter, Chapter 5 , summarizes the results of the pedestrian survey and provides recommendations regarding the expansion project. Also included in Chapter 5 are recommendations related to the potential for encountering archaeological resources on an alternative tract located west of the project area, identified as the Widely Spaced Runway Option.

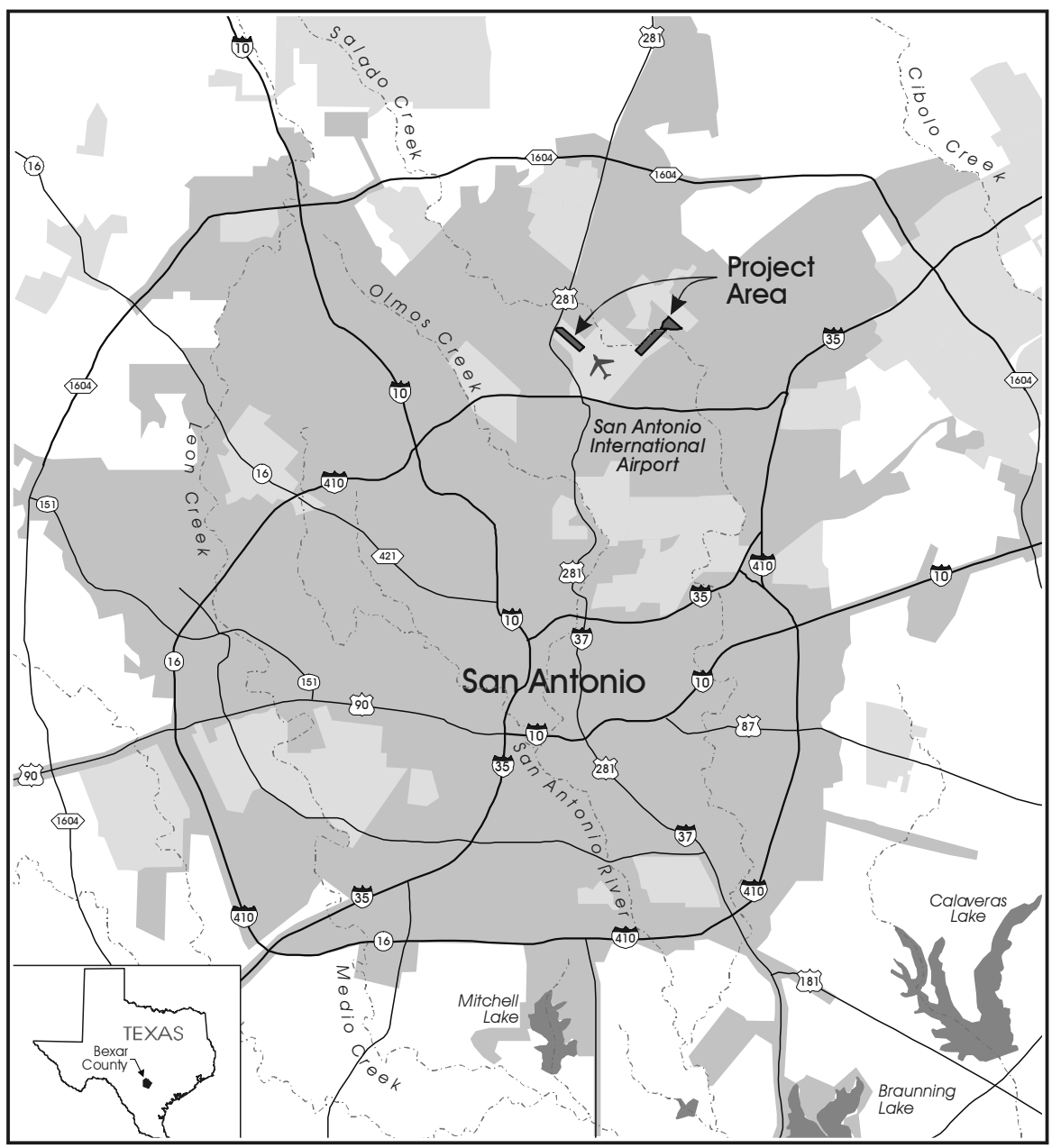

Figure 1-1. Location of the project area in north-central Bexar County, Texas. 
The San Antonio International Airport is located in northcentral San Antonio in the vicinity of the intersection of U.S. Highway 281, Wetmore Road, and NW Loop 410. A portion of the airport property abuts McAllister Park, north of Starcrest Road. The two runway expansions will impact a 75 -acre area (Tract 1) and a 90.2-acre area (Tract 2). Prior to the inception of fieldwork, the final tract slated for development was identified as a 145 -acre tract that included within its boundaries site 41BX959, a previously recorded prehistoric site. A few days after the completion of the survey, Adams Environmental, Inc. informed CAR that the western 100 acres of Tract 3 were not included in the project area. Therefore, the final size of Tract 3 that is part of this project measures only 45 acres. The combined area to be impacted by the expansion and development activities, and therefore representing the Area of Potential Effect (APE), totals 210.2 acres. Figure 1-2 illustrates these areas on the 1992
Longhorn, Texas, 7.5' USGS topographic quadrangle map. Figure 1-3 shows the three tracts on a recent aerial photograph of the project area.

The land being impacted by the project is owned by the City of San Antonio Department of Aviation. As such, the project has to comply with State Historic Preservation laws and specifically the mandates of the Antiquities Code of Texas. In addition, the project is receiving federal funding and therefore must comply with Section 106 of the National Historic Preservation Act (NHPA) of 1966 (as amended through 2000). One outcome of the NHPA was the creation of the National Register of Historic Places (NRHP) and the Advisory Council for Historic Preservation. Section 106 of the NHPA stipulates that the Advisory Council must be given "a reasonable opportunity to comment" regarding the effect of any undertakings that could impact properties that may

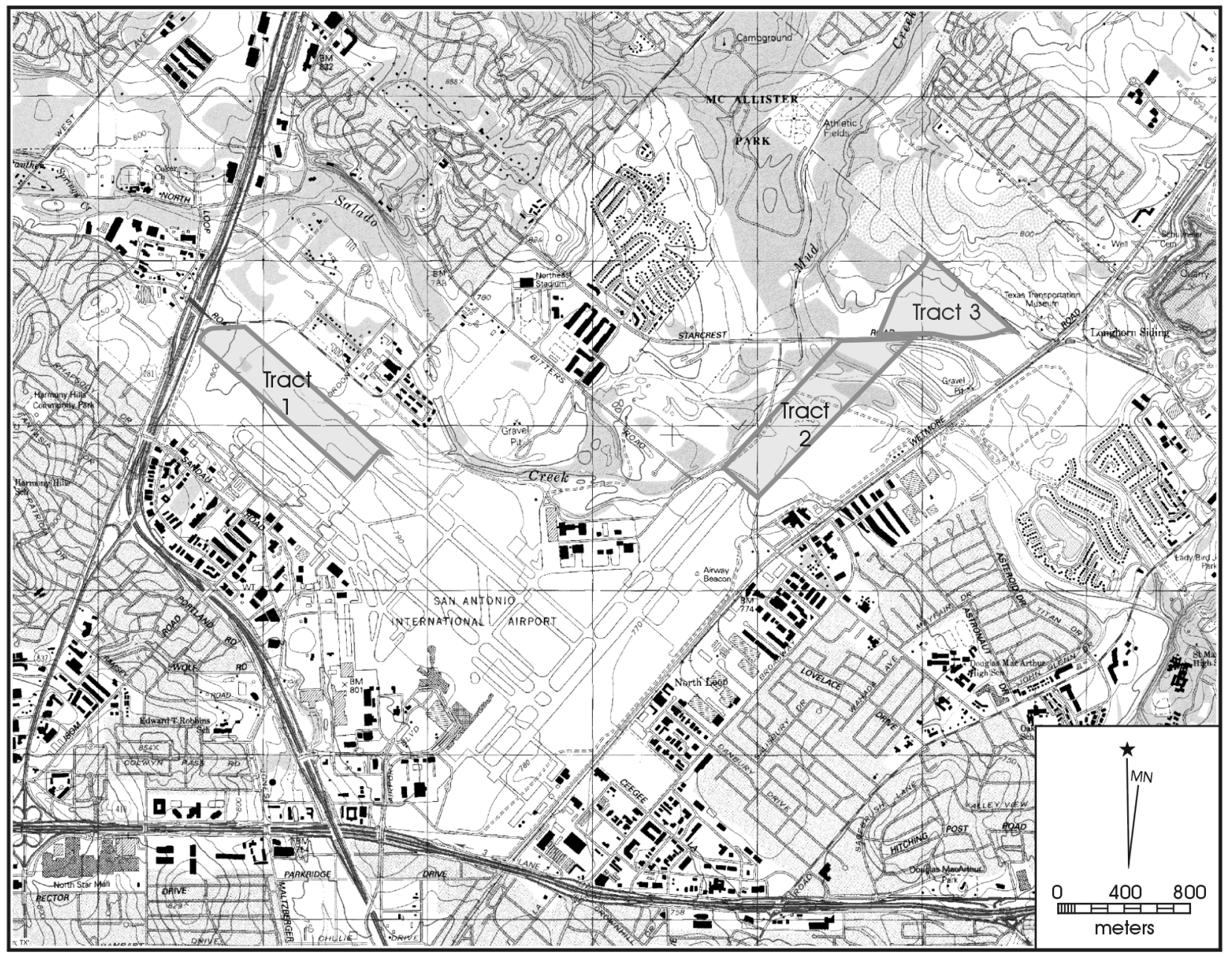

Figure 1-2. Project area on the 1992 Longhorn, Texas, USGS quadrangle map. 


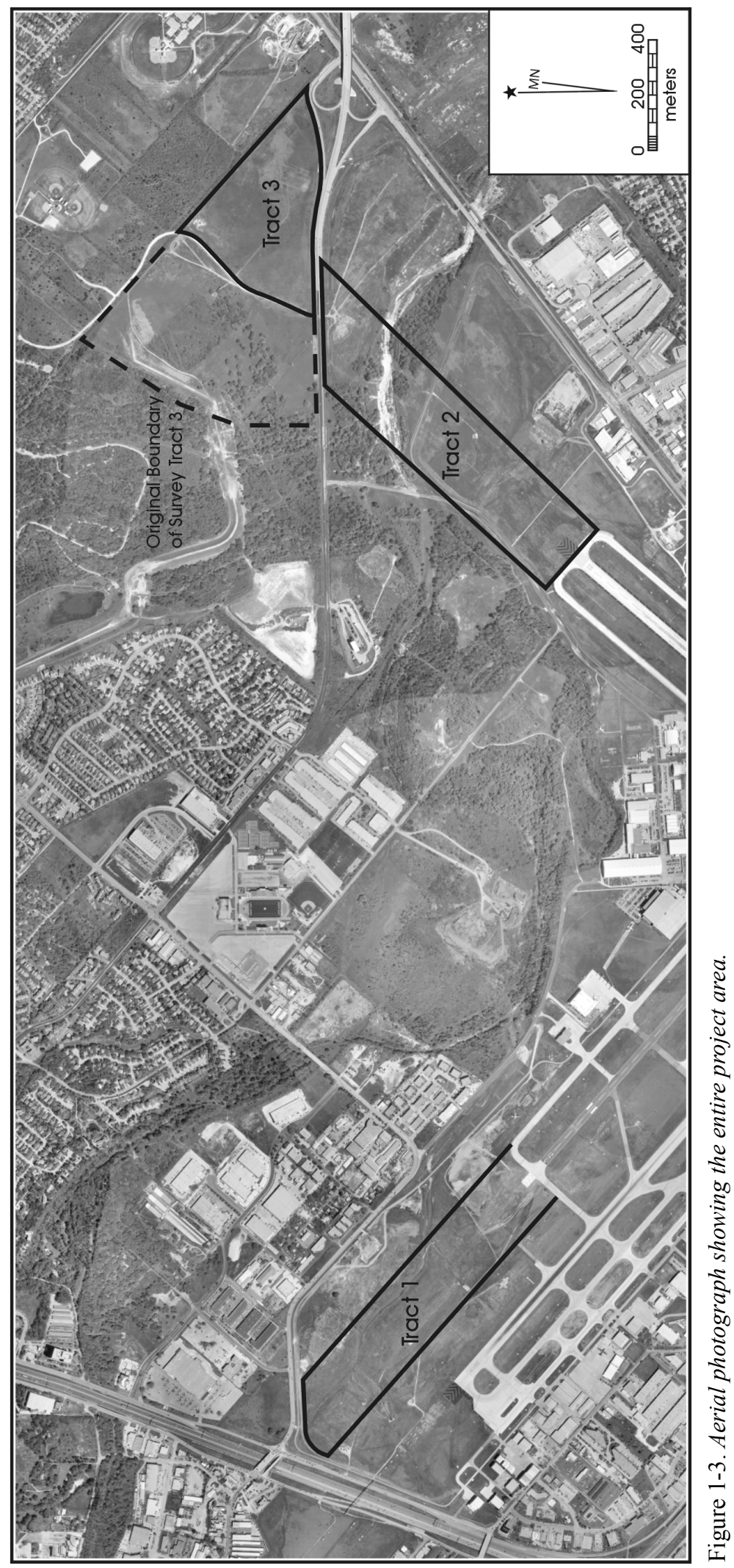


be eligible for inclusion in the National Register. All undertakings that derive from actions funded by, permitted by, or licensed by federal agencies fall under this requirement, as does this runway expansion project.

\section{Scope of Work}

The primary goal of the intensive survey was to locate and document all prehistoric and/or historic archaeological sites within the project area. CAR was to specifically undertake the following:

1. Conduct an intensive 100 percent pedestrian survey accompanied by shovel testing of the 210.2-acre project area, including the areas of proposed expansion of two runways and development of a third tract of land located at the San Antonio International Airport;

2. Excavate a maximum of six backhoe trenches within the project area to determine if any deeply buried deposits remain along the intermittent drainage running through Tract 2 and along the banks of Salado Creek within the APE;

3. Revisit recorded archaeological site 41BX959 located within the [initially defined] APE to assess its preservation status and site boundaries within the current project boundaries;

4. Prepare any artifacts, if found, and all associated documents for curation at CAR's curation facility;

5. Produce a report summarizing the survey methods and results of the survey.

CAR staff revisited and shovel tested site 41BX959 before they were notified that the parcel upon which the site is located fell outside the APE. The 100-acre parcel located immediately west of the reduced Tract 3 is part of McAllister Park and is owned by the City of San Antonio Parks and Recreation Department. Nonetheless, and given that this area and site may be subject to future impacts by the City of San Antonio as it further develops McAllister Park, and at the recommendation of Adams Environmental, Inc., CAR presents the results of the site revisit in Appendix A, rather than in the main body of this report.

\section{Present Condition of the APE}

Aerial photographs of the project area (Figures 1-4 and 1-5) indicate that all three tracts have been dramatically impacted during the original construction of the airport or subsequent expansions of runways. The majority of the impacts in Tracts 1 and 2 consist of clearance of vegetation and significant ground leveling activities. Figure 1-6 shows the north-central portion of Tract 2 and illustrates the degree of ground clearance and leveling that has occurred in the tract. Figure 1-7 shows similar impacts in the eastern portion of Tract 3, on the north side of Starcrest Road.

The confluence of Mud Creek, Salado Creek and an unnamed tributary occurs immediately west of Tract 2. Salado Creek crosses Tract 2 and runs immediately adjacent to but outside of the western border of that tract. At least portions of the banks of Salado Creek crossing Tract 2 appear wooded (see Figure 1-4) and may have suffered less impact than the remainder of the tract. In contrast, the eastdescending bank of Salado Creek running along the western edge of Tract 2 appears to have been heavily impacted by past clearing and leveling activities.

An unnamed tributary to Salado Creek cross-cuts the northern half of Tract 1 and flows along the northern boundary inside the tract. Both banks of this drainage appear to have been heavily impacted by airport construction (see Figure 1-5).

Finally, a review of the 1953 Longhorn, Texas, 7.5' USGS topographic quadrangle map of the area shows major previous impacts within the project area, and particularly within Tract 1 (Figure 1-8). Isom Road and North Loop, as well as several smaller side roads, cross-cut Tract 1 on the 1953 map. While Tract 2 appears to have been the subject of less impact prior to 1953, Tract 3 appears to have been cleared by 1953 and a two-track road traversed it in a southeast to northwest direction. 


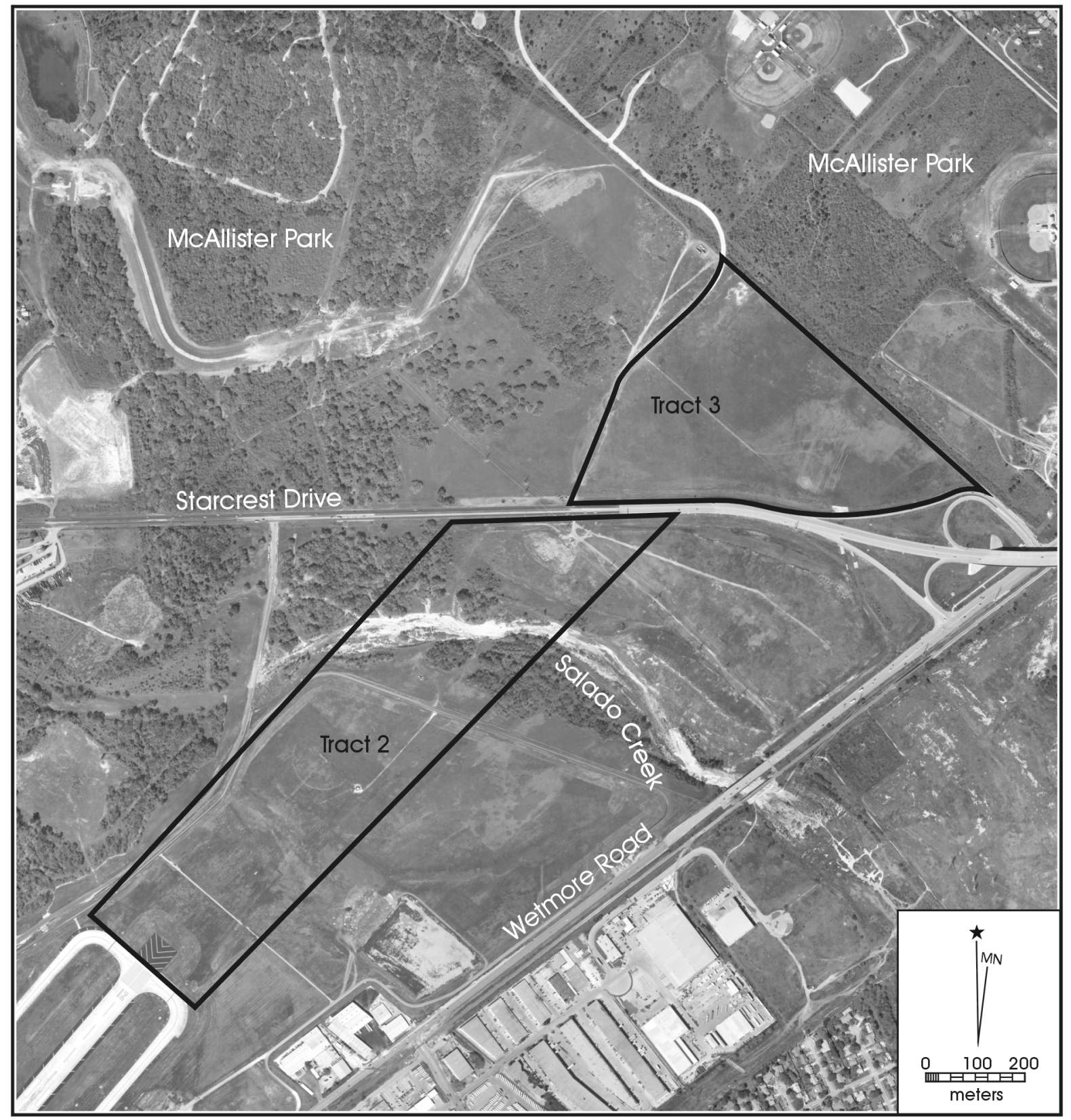

Figure 1-4. Aerial photograph showing the eastern portion of the project area, Tracts 2 and 3. 


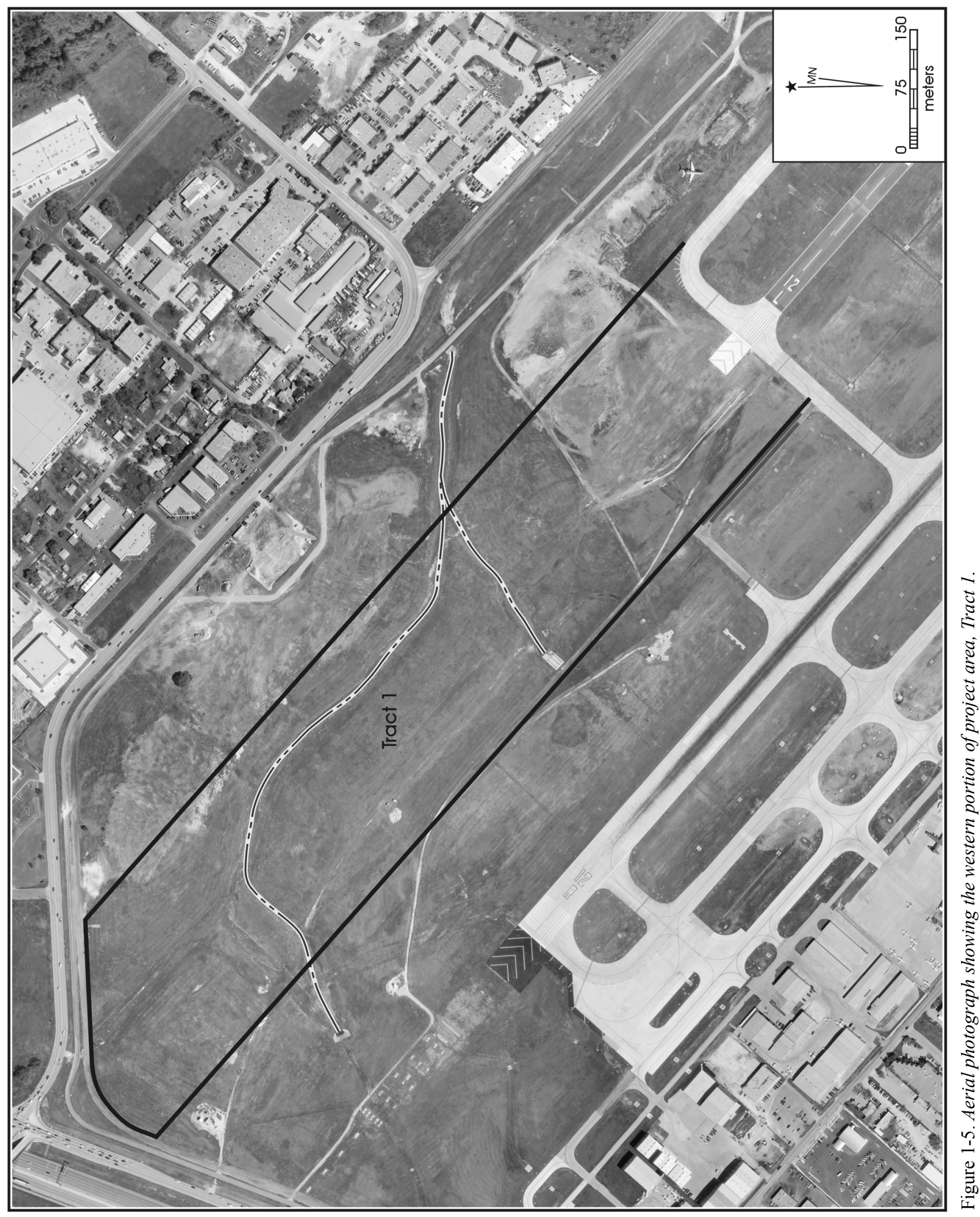




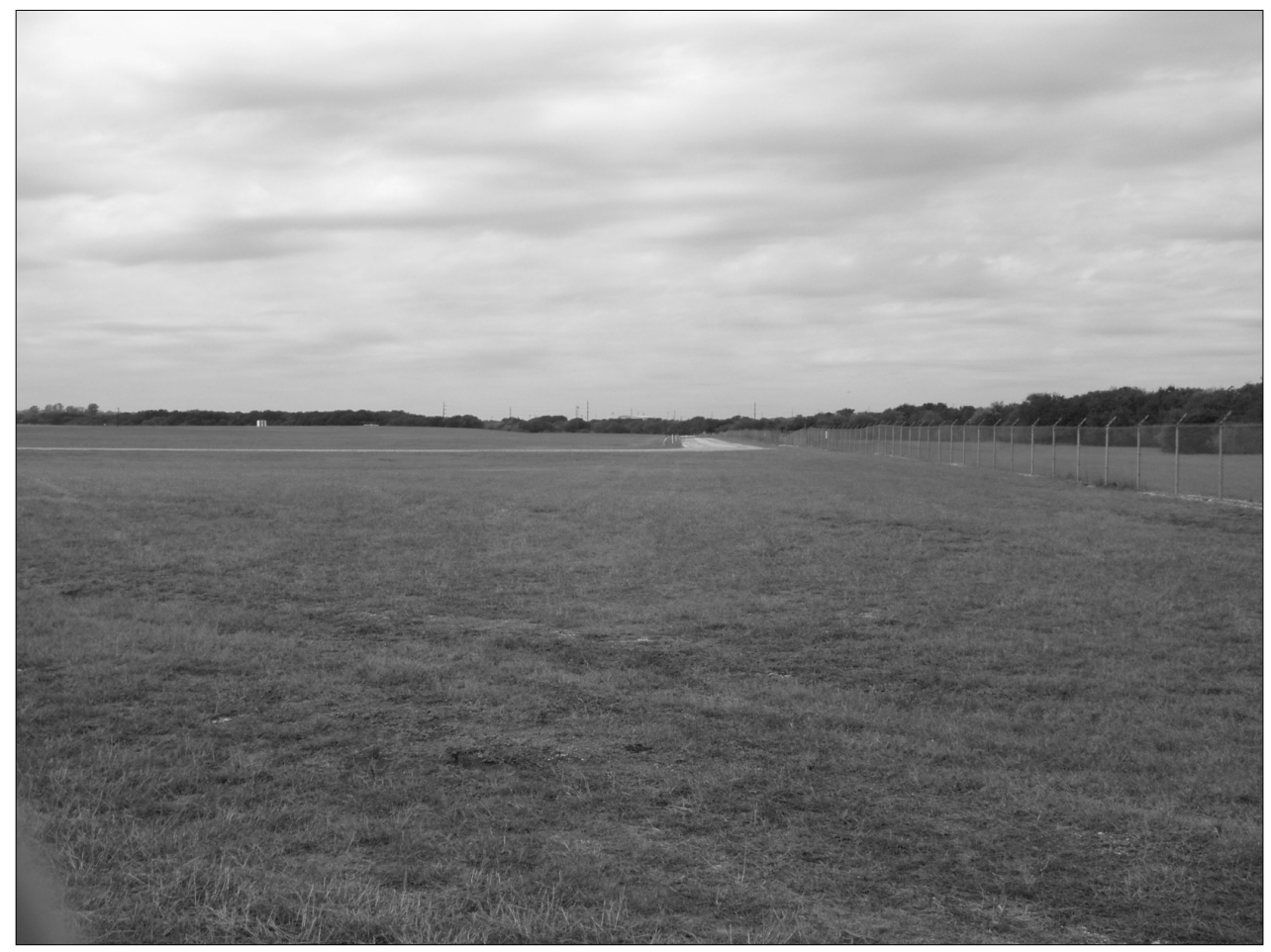

Figure 1-6. Clearance and grading within the north-central portion of Tract 2.

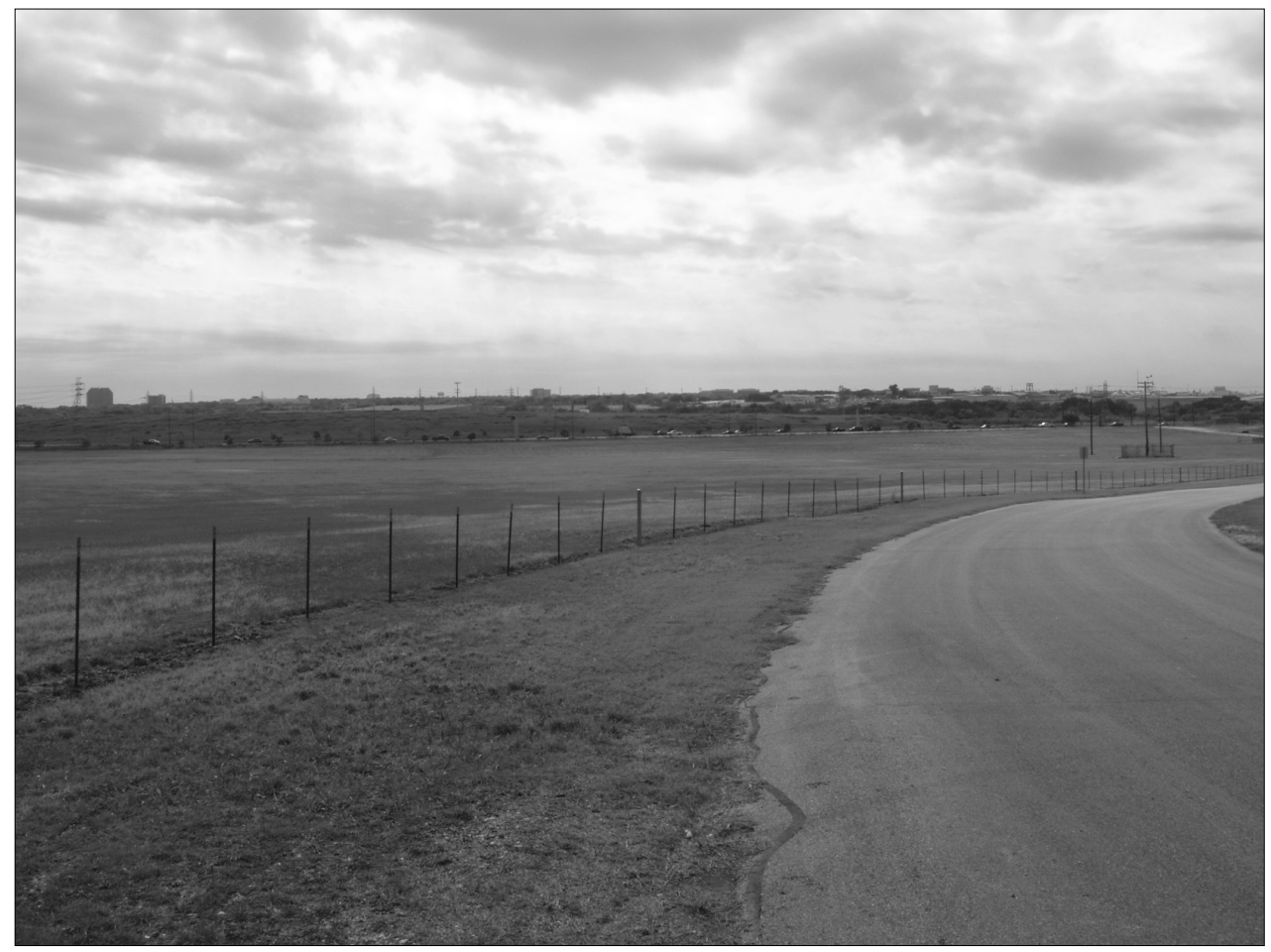

Figure 1-7. Clearance and grading impacts across the eastern portion of Tract 3. 


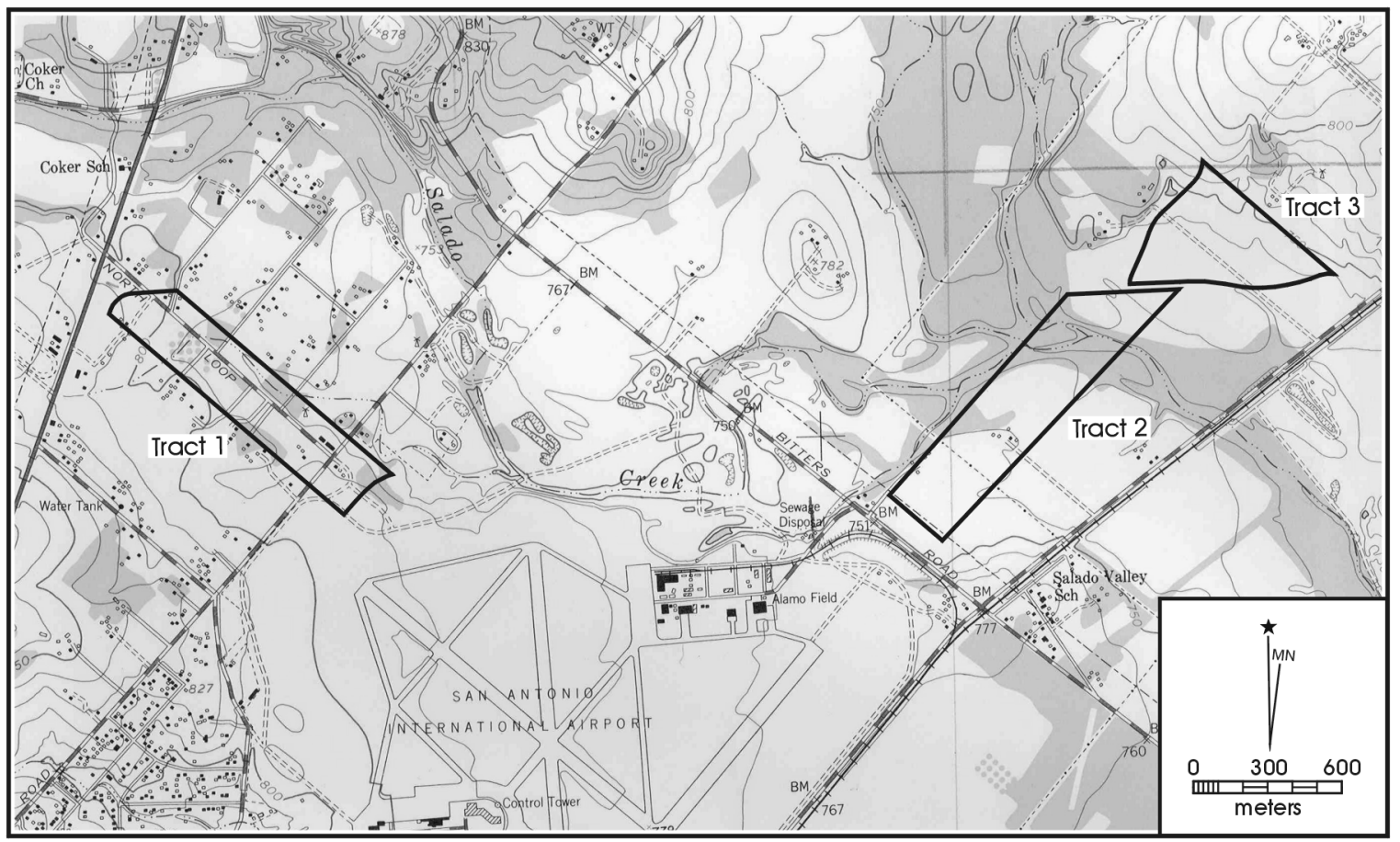

Figure 1-8. The survey tracts depicted on the 1953 Longhorn, Texas, 7.5' USGS topographic quadrangle. 
Survey for San Antonio International Airport Expansion

\section{Chapter 2: Environmental Setting and Previous Archaeological Investigations}

\section{Environmental Setting}

The San Antonio International Airport is located in the northcentral part of the city near the intersection of U.S. Highway 281, Wetmore Road, and NW Loop 410. A section of airport property abuts McAllister Park north of Starcrest Road. Salado Creek, Mud Creek and an unnamed tributary flow through the northern portion of the airport property near the runway expansion in Tract 2. An additional unnamed drainage runs through much of Tract 1 (see Figure 1-5). Both of the named creeks have seen numerous archaeological surveys with the majority revealing archaeological sites along their banks. A number of surveys within McAllister Park have also documented a number of sites within the park boundaries.

Bexar County is rich with cultural resources from the prehistoric and historic time periods. Archaeological excavations have uncovered remains from all periods of known human habitation: Paleoindian (ca. 11,000-8000 BP), Archaic (ca. 8000-1150 BP), Late Prehistoric (ca. 1150350 BP; Hester 1995), and through to the present.

The current project is located within the Nueces-Guadalupe Plain biogeographical area of the South Texas Plain (Black 1989). The Balcones Escarpment that runs through San Antonio provides an excellent source of streams and diverse vegetation that made the region a favorable camping spot in prehistoric times. The area is especially rich in archaeological sites dating to the Early Archaic as documented by surveys and testing projects across the Salado Creek watershed (Johnson 1991; Tomka et al. 1997). Private and governmental agencies have conducted these surveys and archaeological stewards have aided in recording other sites not encountered during larger surveys. Some of the more important sites in the area have received intensive excavations (Black and McGraw 1985; Fox 1979; Hudson et al. 1974; Katz 1987; Potter and Black 1995).

The San Antonio International Airport is located near many creeks with important archaeological deposits along their banks. Salado Creek, Panther Springs Creek, Mud Creek and Olmos Creek all run within a few miles of the project area. Archaeological site types in the watershed include residential camps, cemetery sites (Lukowski 1988), and various lithic procurement localities (Potter and Black
1995). In the remainder of this chapter we summarize the survey work and recorded archaeological sites in or near the project area.

\section{Previous Archaeological Investigations}

\section{San Antonio International Airport Survey}

Only one survey is listed on the Texas Archeological Sites Atlas (Texas Historical Commission [THC] 2005) within the San Antonio International Airport grounds. J. Eaton conducted the survey in 1979 for inventory of cultural resources that may be impacted by runway expansions. No sites were located during the investigations.

\section{McAllister Park Investigations}

A section of airport property abuts McAllister Park which has seen several archaeological investigations. The park was created in 1966 as a recreation facility for the citizens of San Antonio. In 1972, Anne Fox (of CAR) conducted a pedestrian survey of the park to inventory its cultural resources. She identified three sites on the east bank of Mud Creek: a habitation site (41BX172), a lithic scatter (41BX173), and a lithic procurement site (41BX174; Fox 1973; Tomka and Robinson 2000). These sites were revisited in 1974 by personnel from CAR (Hester et al. 1974). Only site 41BX174 appeared worthy of further study.

No other surveys were conducted in the park until 2000, when staff from CAR surveyed a portion of the park slated for road improvements. Three sites were recorded: 41BX1410, 41BX1411 and 14BX1412. Sites 41BX1410 and 41BX1411 were identified as surface lithic scatters exhibiting multiple stages of lithic reduction. Site 41BX1412 was recorded as a multicomponent site on an upland terrace of Mud Creek. This site was later the subject of data recovery excavations (Tomka and Robinson 2000).

CAR staff conducted further excavations based on buried deposits of primary and secondary flakes, bifaces and cores interspersed with historic artifacts from the 1930s to modern times. Temporally diagnostic artifacts observed during the investigations included Guadalupe adzes, a split stem dart 
point, and a drill made from a recycled lanceolate point. Scrapers, reamers, and gravers were also recovered in test units and shovel tests. Testing suggested the presence of an Early Archaic, and a possible late Paleoindian, component at the site, however, data recovery excavations indicated that although an Early Archaic cultural zone may exist at the site, buried some $60 \mathrm{~cm}$ below surface, no in situ temporal diagnostics were recovered from this zone. Instead, these efforts yielded Middle Archaic temporal diagnostics but no intact deposits. CAR personnel concluded that the site had seen significant disturbance during previous construction of Bee Drive (Tomka 2002).

Additional investigations were conducted in McAllister Park by CAR in 2001 (Zapata 2002). This work included survey and shovel testing carried out in response to a proposed parking lot extension and road spur. The survey and shovel testing failed to locate any significant in situ prehistoric or historic artifacts or cultural features.

Other known sites within McAllister Park, near Tract 3 of the current APE, are 41BX172 and 41BX173. These sites are severely eroded lithic scatters containing stone tools and debitage. Site 41BX949 sits near Tract 2. This open campsite sits on a terrace between Salado Creek and its tributary and contains evidence of a burned rock midden. This site was investigated during a larger testing project of five sites along Wurzbach Parkway. It was found to have shallow deposits of artifacts in secondary contexts and considered ineligible for nomination to the NRHP (Potter and Black 1995).

\section{Watershed Surveys}

Salado Creek, Mud Creek, and an unnamed tributary flow through the northern portion of the airport property near the runway expansion in Tract 2 . An additional unnamed drainage runs through much of Tract 1. Salado and Mud creeks have seen numerous archaeological surveys with the majority revealing archaeological sites along the banks of the creeks. Panther Springs Creek joins Salado Creek to the northwest of the airport and was also an important drainage in prehistoric times.

\section{Salado Creek and Panther Springs Creek}

Numerous surveys of the Panther Springs Creek and Salado Creek watersheds are outlined in the Texas Archeological Sites Atlas (THC 2005). Most of the recorded sites near the confluence of these creeks lie on 1,500 acres known as Walker Ranch. The THC carried out a reconnaissance of the property and recorded 41 archaeological sites dating from the prehistoric to the historic periods. Sites found within the Walker Ranch lands occupy a variety of geographical and environmental situations but the majority sit within 30 meters of a waterway. Sites were recorded on primary and secondary terraces, slopes and hill tops. Most sites are surface scatters of lithic debris and burned rock in no obvious pattern. Four sites are listed as burned rock midden sites with circular or oval mounds of fire-cracked limestone. Of the 41 sites recorded, three were subject to further investigation: 41BX180, a nineteenth-century ranch; 41BX228, a multicomponent burned rock midden site; and 41BX197, a large, open terrace site (Hudson et al. 1974).

\section{The Walker Ranch Site (41BXI80)}

Site 41BX180, tested by the THC, consists of the ruins of a limestone corral wall, two structures and three possible cisterns. The corral wall encloses $110-125$ acres and is constructed of quarried limestone. Several archaeological surveys have been conducted at the Walker Ranch Site (Fox 1979; Hudson et al. 1974; Scurlock and Hudson 1973). Scholars have suggested that the site is Spanish colonial while others date it to the mid-nineteenth century. It was nominated to the NRHP in 1975 for its significance in the area of early agriculture.

\section{The Panther Springs Creek Site (41BX228)}

Testing of this site by the THC included placement of a 1-x-2-meter test unit over a rock midden visible on the surface. Surface collection and excavations revealed numerous artifacts $(\mathrm{n}=2,799)$ including stone, bone and shell (Hudson et al. 1974).

The investigations at 41BX228 partially mitigated the loss of cultural information caused by looters and by a proposed flood control project. This work took place in 1979 and included mapping, testing, backhoe trenching, and the excavation of several block areas. The investigations produced large quantities of lithic, ceramic, and bone artifacts as well as faunal and botanical remains. A study of site use, development, and settlement patterns in the Salado Creek drainage is discussed in the site report (Black and McGraw 1985). The site has seen subsequent re-evaluation as development in the area encroaches on the site boundaries (Hester el al. 1974; Potter and Black 1995).

In 1976 and 1977, CAR conducted a survey to assess the impact to cultural resources of a wastewater treatment facility (Fox 1977). This survey resulted in the reassessment or discovery of 39 sites. Six of these (three historic and three prehistoric) were recommended for further testing. 


\section{Mud Creek}

Sites along Mud Creek in the vicinity of the current project area, outside of McAllister Park, also occupy terraces and contain surface lithic scatters. Site 41BX959 lies within the original proposed boundaries of Tract 3 of the current project area. This site was recorded as a lithic procurement site by archaeological steward C. K. Chandler in 1991. The site contained surface cobbles, flakes, bifaces, burned rock, and dart points across an area measuring 80 meters by 240 meters at the time of its initial recording.

Sites 41BX353 and 41BX458 lie to the northwest of Tract 3 . They are lithic scatters situated on the terrace above Mud Creek. Site forms for both sites report surface lithic debitage across open areas. In 1977, site 41BX353 was recorded by J. A. Jaquier based on observed surface artifacts scattered over a 20 -meter by 10 -meter area. Artifacts noted included utilized flakes, scrapers, and debitage. At the time of its recording, a dirt road transected the site. Also in 1977, site 41BX458 was recorded as a lithic surface scatter measuring approximately 75 meters by 30 meters. Artifacts observed included large flakes, cobbles and dense debitage.

The literature search for archaeological work within or near the project area produced a wealth of information pertinent to prehistoric and historic Bexar County. The county's geographical and biotic situation made the region favorable for early humans to access a large assortment of resources. We would expect that undeveloped areas could still have potential for archaeological sites on nearly any landform, but particularly those situated near reliable water sources. 


\section{Chapter 3: Fieldwork Accomplished and Laboratory Procedures}

\section{Field Methods}

Given the level of previous impact to the project area noted in Figures 1-4 and 1-5, and the mix of creek-proximate and -distant areas, in the scope of work for the project, CAR divided the project into moderate and low probability areas based on an area's potential to contain buried sites and the degree of previous disturbance. For the purposes of this survey, the areas located on the banks of creeks and tributaries within 30 meters of the banks of the channel were considered moderate probability areas. Such moderate probability areas are located at the north end of Tract 2 where Salado Creek crosses the tract, and at the western end and along the northern edge of Tract 1 where the drainage of an unnamed tributary crosses the tract. Areas farther away from creek channels or in upland settings were considered low probability settings where sites would be found exposed on surface or would be shallowly, rather than deeply, buried. Using this approach, prior to the inception of the survey, with the exception of the moderate probability areas noted above, the remainder of the project area was perceived as having a low probability of containing sites in deeply buried contexts. Based on a brief visit to the project area prior to the inception of the survey, it appeared that nearly all of the low probability areas across the project area have been heavily impacted through land clearing and sculpting associated with the construction of the airport and previous improvements.

Based on the presence and distribution of these moderate and low probability areas within the three tracts subject to construction-related impacts, CAR conducted a 100 percent pedestrian survey of the 210-acre APE. The levels and types of survey methods proposed were described in the scope of work that accompanied the Texas Antiquities Committee permit application (on file at the Center for Archaeological Research). The pedestrian survey involved a combination of shovel testing and backhoe trenching as subsurface site discovery methods. The surface was inspected while crews traversed the tracts along transects spaced at 20-meter intervals.

Subsurface inspection of the project area varied based on whether the area was considered to have moderate or low probability for buried sites. In the original scope of work, and without prior inspection of the tract, we had proposed to excavate 11 shovel tests along each bank of the drainage crossing Tract 1, for a total of 22 shovel tests. Given the heavily disturbed nature of the remainder of the tract, we proposed to excavate one shovel test for every three acres, for a total of 25 shovel tests in the low probability portions of the tract. While a total of 47 shovel tests were planned for Tract 1 , massive disturbed areas were identified during the first few shovel tests excavated in the vicinity of the two drainages within the moderate probability area, as well as in the remaining low probability area within the tract. Therefore, only 14 shovel tests were excavated in Tract 1 (Figure 3-1).

In Tract 2, CAR proposed to excavate eight backhoe trenches along the moderate probability area of the opposite banks of Salado Creek. In addition, CAR proposed to hand excavate a shovel test every 25 meters between each of the backhoe trenches. This strategy was to produce eight shovel tests. For the remaining low probability portion of Tract 2 , CAR proposed to excavate one shovel test for every three acres, resulting in the excavation of 30 shovel tests. Overall, this strategy was to result in the excavation of eight backhoe trenches and 38 shovel tests within Tract 2.

As the backhoe trenching began in Tract 2, few prehistoric artifacts were noted in the trenches, the stratigraphy was indicative of high-energy food deposits, and at least one trench revealed recent materials characteristic of a dump or landfill. In addition, the pedestrian survey and shovel tests confirmed the highly altered nature of much of the area contained within Tract 2 . Therefore, only five backhoe trenches and 19 shovel tests were excavated in Tract 2 (Figure 3-2).

Tract 3 , as eventually defined, measured 100 acres within a valley margin/upland setting. The entire area was deemed as having low probability for containing buried sites. Based on the pre-survey inspection of high-resolution aerial photographs and the brief visit to the project area prior to the survey, it was assumed that this tract had been heavily disturbed through clearance and grading at the time of the airport construction. This is evident in the artificial shape of the contour lines notable on the 1953 Longhorn, Texas, quadrangle map (see Figure 1-8, Tract 3). CAR proposed to excavate three shovel tests every three acres resulting in 33 shovel tests in Tract 3. 


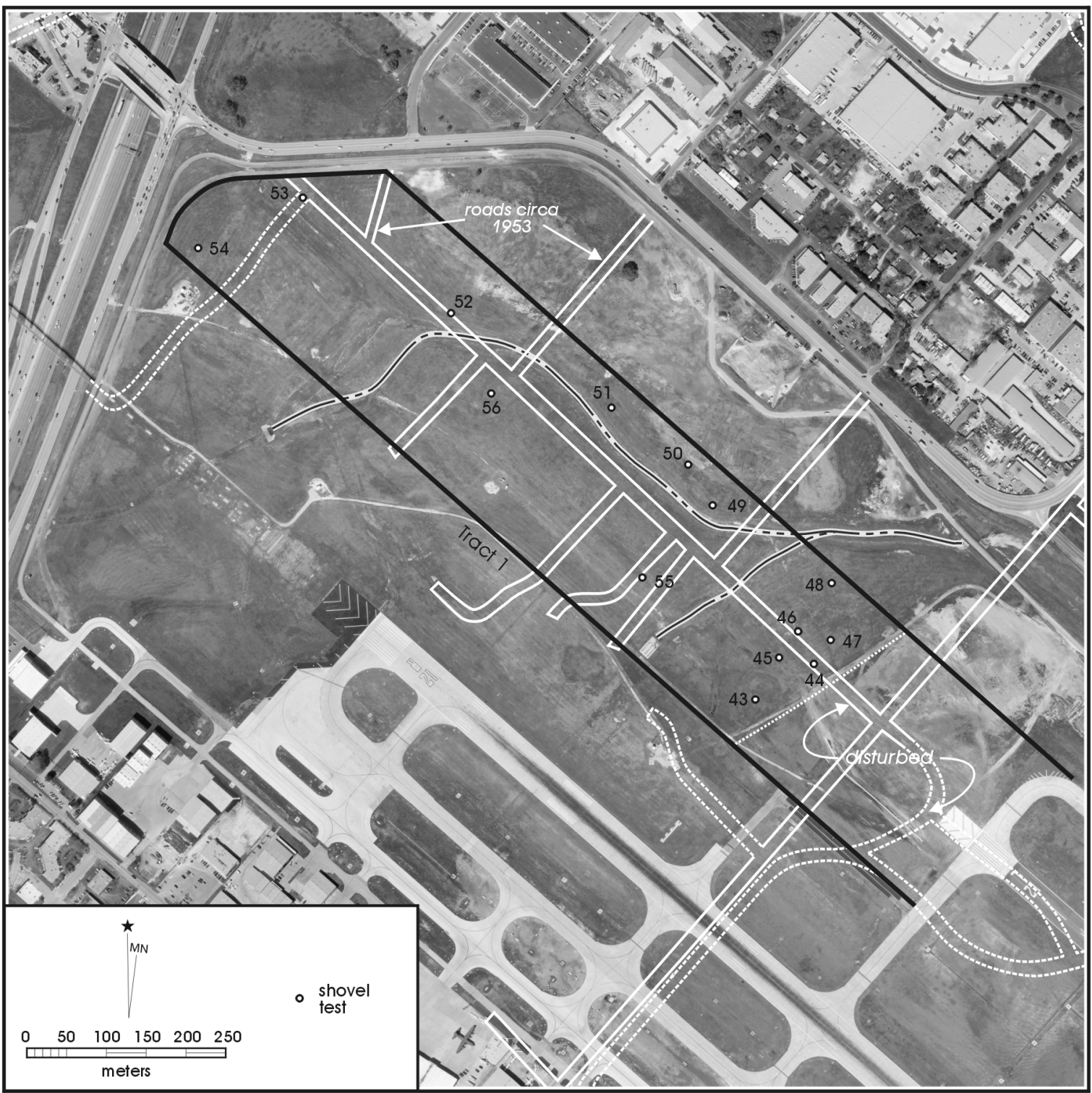

Figure 3-1. Locations of shovel tests excavated in Tract 1. Note old road system superimposed from 1953 USGS quadrangle.

Finally, because at the time the scope of work was prepared and the survey was conducted the original boundary of Tract 3 included the 100 acres that contained site 41BX959, CAR had proposed to excavate up to 15 shovel tests to sample subsurface deposits and establish their depth. Up to five additional shovel tests were to be excavated if necessary to obtain sufficient information to determine the State Archeological Landmark and National Register of Historic Places eligibility of the site. Another 33 shovel tests were to be excavated in the remaining western section of Tract 3 .
As the survey of the eastern portion of Tract 3 began, it became evident that the original assessment of the degree of disturbance within the tract was an underestimate. A considerable amount of topsoil appears to have been removed from the area and the construction of a storage facility, roads, and parking areas appear to have further impacted the area. Therefore, in search of remaining intact deposits, the CAR crew excavated only 21 shovel tests within Tract 3 (Figure 3-3). 


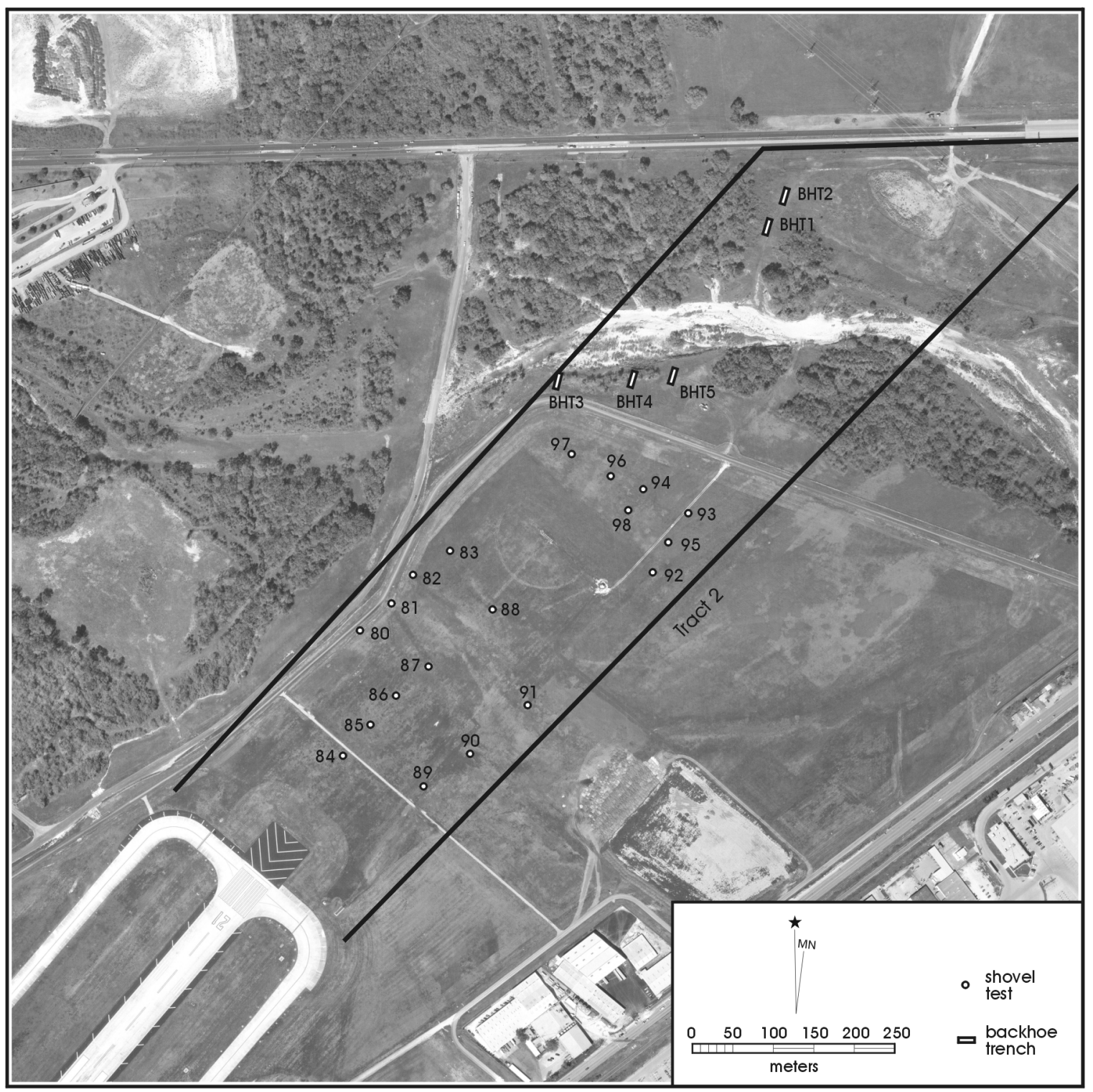

Figure 3-2. Locations of shovel tests and backhoe trenches excavated in Tract 2.

In addition, because the CAR survey crew was not notified of the fact that the western portion of Tract 3 was not part of the project until after the survey was concluded, the staff also excavated 27 shovel tests within site 41BX959 and five shovel tests in the extreme northern corner of the tract where it was ascertained that undisturbed deposits may have been preserved (see Appendix A).
Overall, the intensive pedestrian survey resulted in the excavation of five backhoe trenches and 54 hand-excavated shovel tests. The five backhoe trenches and five of the shovel tests were excavated in moderate probability areas. The remaining 49 shovel tests were placed at the discretion of the project archaeologist within low probability areas to either document the degree of disturbance present in the 


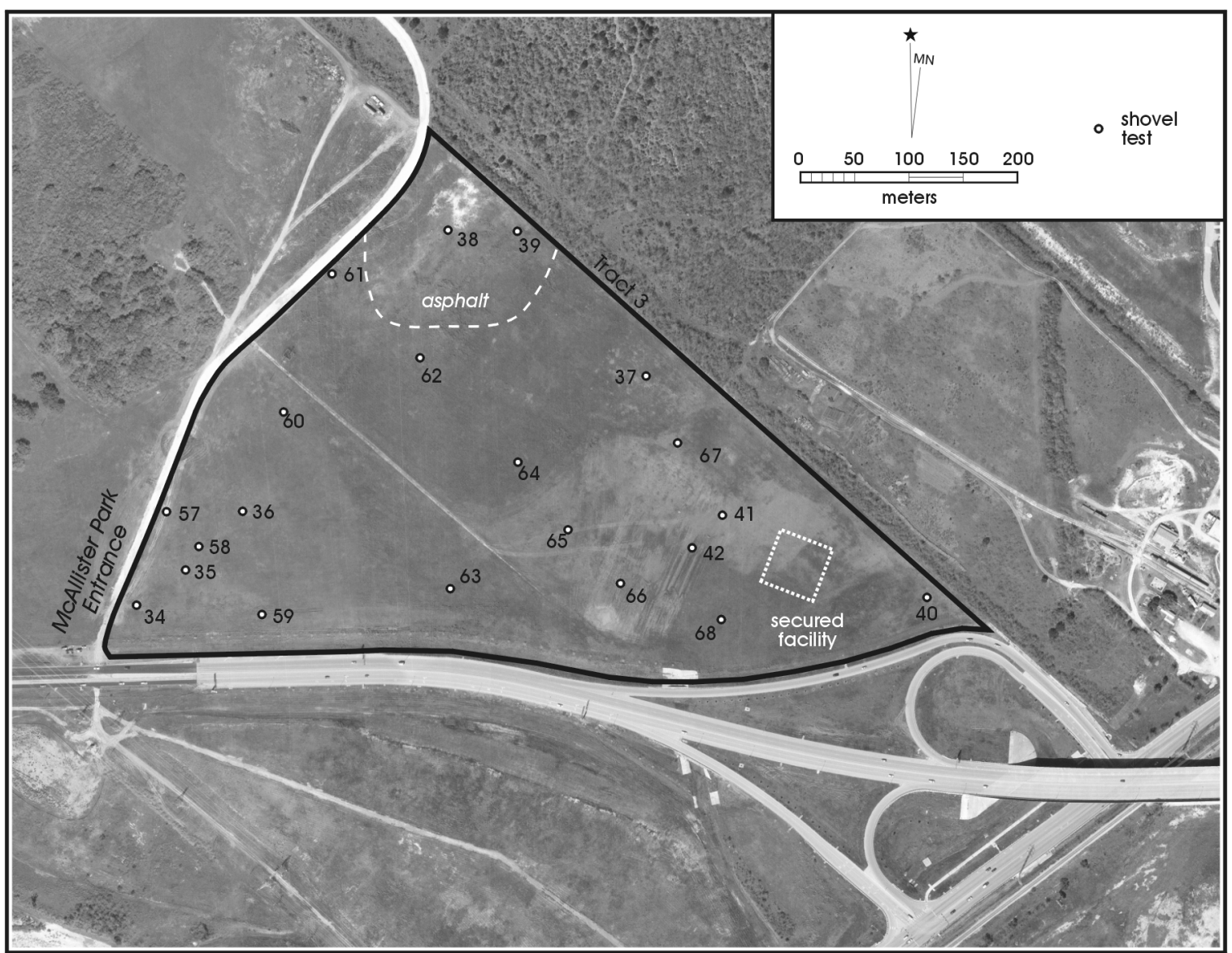

Figure 3-3. Locations of shovel tests excavated in Tract 3.

tract or search for undisturbed deposits and archaeological remains. In addition, 32 shovel tests were excavated in the originally defined western section of Tract 3 , of these, 27 were dug in 41BX959.

The shovel testing entailed the systematic excavation of test pits measuring $30-\mathrm{cm}$ in diameter. Each shovel test reached a maximum of $60 \mathrm{~cm}$ below ground surface, unless otherwise prevented from reaching that depth. The shovel tests were excavated in 10-cm-thick levels and the deposits from each level were screened through $1 / 4$-inch mesh. All artifacts found in the shovel tests were collected and bagged by provenience and returned to the CAR laboratory for processing and analysis.

A standardized shovel test form was completed for each shovel test, even if no artifacts were recovered. All artifacts collected from shovel tests were recorded on the forms.
Observations were also made about the nature of the deposits seen in each test, the final excavation depth, and the texture, consistency, color, and inclusions present within the soil. All shovel test locations were mapped using a Trimble GeoExplorer II Global Positioning System (GPS) unit. Shovel test locations were also mapped on topographic quadrangle maps and aerial photographs of the project area as backups to the GPS data.

All backhoe trenches were excavated to a depth of 1.5 meters below surface and were at least five meters in length. No soils were screened from these trenches but observations were made on the soil stratigraphy and any artifacts exposed. A segment of one wall of each trench was profiled, however, only backhoe trenches reflecting different depositional processes were documented. All backhoe trench locations were mapped using a GPS unit. They were also mapped onto topographic quadrangle maps and aerial photographs. 
When crew members encountered artifacts in a shovel test or observed a concentration of artifacts on surface, they excavated additional shovel tests in the vicinity of the positive unit, except in cases where it was clear that the deposits were heavily disturbed. If it could be discerned from the positive shovel test and surface evidence that the area was heavily disturbed, no additional shovel tests were excavated in the vicinity of a positive test.

The minimum requirements employed during this survey for the presence of cultural materials to constitute a site were as follows:

1. Locations having a minimum of five artifacts within a $30-\mathrm{m}^{2}$ area or a single positive shovel test having at least five artifacts present; or

2. A location containing a single cultural feature; or

3. A location containing subsurface evidence of a feature, such as a hearth.

Artifact finds that did not constitute a site as defined above were classified as isolated finds. Isolated finds encountered on the surface were not collected unless they represented temporally diagnostic specimens. All finds from shovel tests and backhoe trench wall profiling were collected. However, debris representing land fill material was not collected during backhoe trenching.

As part of the work conducted at 41BX959, the crew redefined the site boundaries based on positive shovel tests and surface artifact distributions. All artifacts from positive shovel tests were collected, while only temporally diagnostic surface artifacts were collected and their locations mapped with a GPS unit and sketched on the site map.

\section{Laboratory Procedures}

All cultural materials and records obtained and/or generated during the project were prepared in accordance with federal regulation 36 CFR part 79, and THC requirements for State Held-in-Trust collections. Artifacts processed in the CAR laboratory were washed, air-dried, and stored in 4-mil ziplocking archival-quality bags. Acid-free labels were placed in all artifact bags. Each label contains provenience information and a corresponding lot number laser printed or written in pencil. The few tools and/or non-debitage artifacts encountered were labeled with permanent ink over a clear coat of acrylic and covered by a second acrylic coat. In addition, a small sample of unmodified debitage from each lot was labeled with the appropriate provenience data. Artifacts were separated by class and stored in acid-free boxes identified with standard tags.

Field notes, forms, photographs, and drawings were placed in labeled archival folders. Photographs, slides, and negatives were labeled with archivally appropriate materials and placed in archival-quality sleeves. All field forms were completed with pencil. Documents and forms were printed on acid-free paper and any soiled forms were placed in archival-quality page protectors. Maps and illustrations produced by ink-jet printers also were placed in archivalquality page protectors. A copy of this survey report and all computer disks pertaining to the investigations were curated with the field notes and documents.

The materials recovered during the survey were entered into an Access database and Excel spreadsheet to aid in data exploration and to serve as a catalog of the artifacts associated with the project. Subsequent to the quality check of the laboratory processing, materials that were incorrectly identified as cultural were discarded. These materials consisted of natural clasts and naturally fractured chert pieces identified as cultural materials in the field. In addition, four post-1950 pieces of glass and a single piece of fire-cracked rock were also discarded. All artifacts that were retained and all documentation pertaining to the project are permanently curated at the CAR facility. 


\section{Chapter 4: Results of Field Investigations}

During March and April of 2005, CAR conducted a 100 percent intensive pedestrian survey of the project area. Shovel testing was conducted on all three tracts and backhoe trenching was carried out in the northern portion of Tract 2, along the banks of Salado Creek. Site 41BX959 was relocated in the western section of Tract 3. At the time of the survey, CAR staff had not been informed that this section of Tract 3 was no longer part of the project area. The boundaries of 41BX959 were redefined based on shovel testing and surface distribution of cultural materials and a historic component was identified on site. A portion of Tract 2 and the entirety of Tract 1 were considered high security areas, and while in these areas the archaeological crew was escorted by Mr. Kao Lin Chen from the airport Planning and Engineering Department.

\section{Tract 1}

Fourteen shovel tests (STs 43-56) were excavated in Tract 1 (Figure 3-1). Their terminal depths and the deposits they encountered are presented in Table 4-1. Five of the shovel tests (STs 49-52 and 54) were excavated in the moderate probability area along the larger of the two drainages crossing the tract.
Figure 3-1 presented the shovel test locations in relation to the 1953 road system in the area. None of the shovel tests reached the planned $60 \mathrm{~cm}$ below surface $(\mathrm{cmbs})$ terminal depths. Instead, $11(79 \%)$ of the units were terminated at the base of Level $1(0-10 \mathrm{cmbs})$ upon encountering asphalt $(\mathrm{n}=3)$, road base $(\mathrm{n}=7)$ or highly compacted fill $(\mathrm{n}=1)$. Only one shovel test (ST 46) was dug two levels into the road base. The deepest shovel test (ST 55) was excavated to a depth of $42 \mathrm{cmbs}$ and encountered grayish brown mottled clay capping a light brown sandy matrix.

The southeastern portion of Tract 1 adjacent to the runway has been heavily disturbed due to ground leveling for the installation of runway lights (Kao Lin Chen, personal communication 2005). For that reason, and other security purposes, no shovel tests were excavated in this area (Figure 4-1). It is evident from Figure 3-1 that the southern bank of the main unnamed drainage has been heavily disturbed through road construction. In addition, and as indicated by the shovel tests on the north bank of the drainage (STs 4952 ), the disturbance extended north of the channel (Figure 4-2). Therefore, it is clear that while the area was originally considered to have a moderate probability for prehistoric sites, the degree and extent of previous disturbance has

Table 4-1. Terminal Depths of Shovel Tests Excavated in Tract 1

\begin{tabular}{|c|c|c|}
\hline ST \# & Max. Depth (cmbs) & Disturbance \\
\hline 43 & 10 & asphalt \\
\hline 44 & 10 & asphalt \\
\hline 45 & 10 & road base \\
\hline 46 & 20 & road base \\
\hline 47 & 10 & asphalt \\
\hline 48 & 10 & road base \\
\hline 49 & 10 & road base \\
\hline 50 & 8 & road base \\
\hline 51 & 10 & road base \\
\hline 52 & 10 & road base \\
\hline 53 & 10 & road base \\
\hline 54 & 10 & road base \\
\hline 55 & 42 & fill \\
\hline 56 & 10 & compacted \\
\hline
\end{tabular}




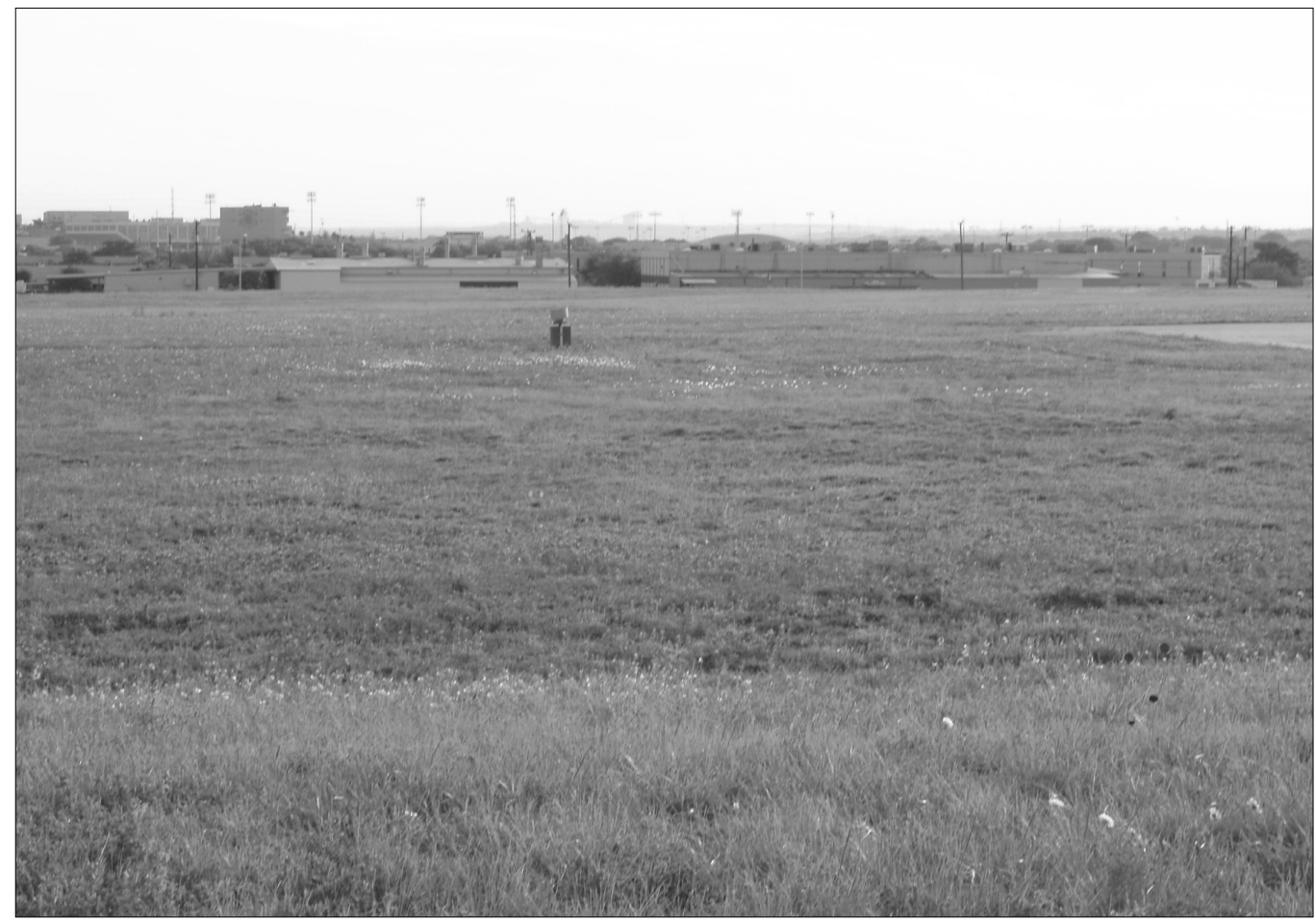

Figure 4-1. Tract 1, area adjacent to runway (runway to the right).

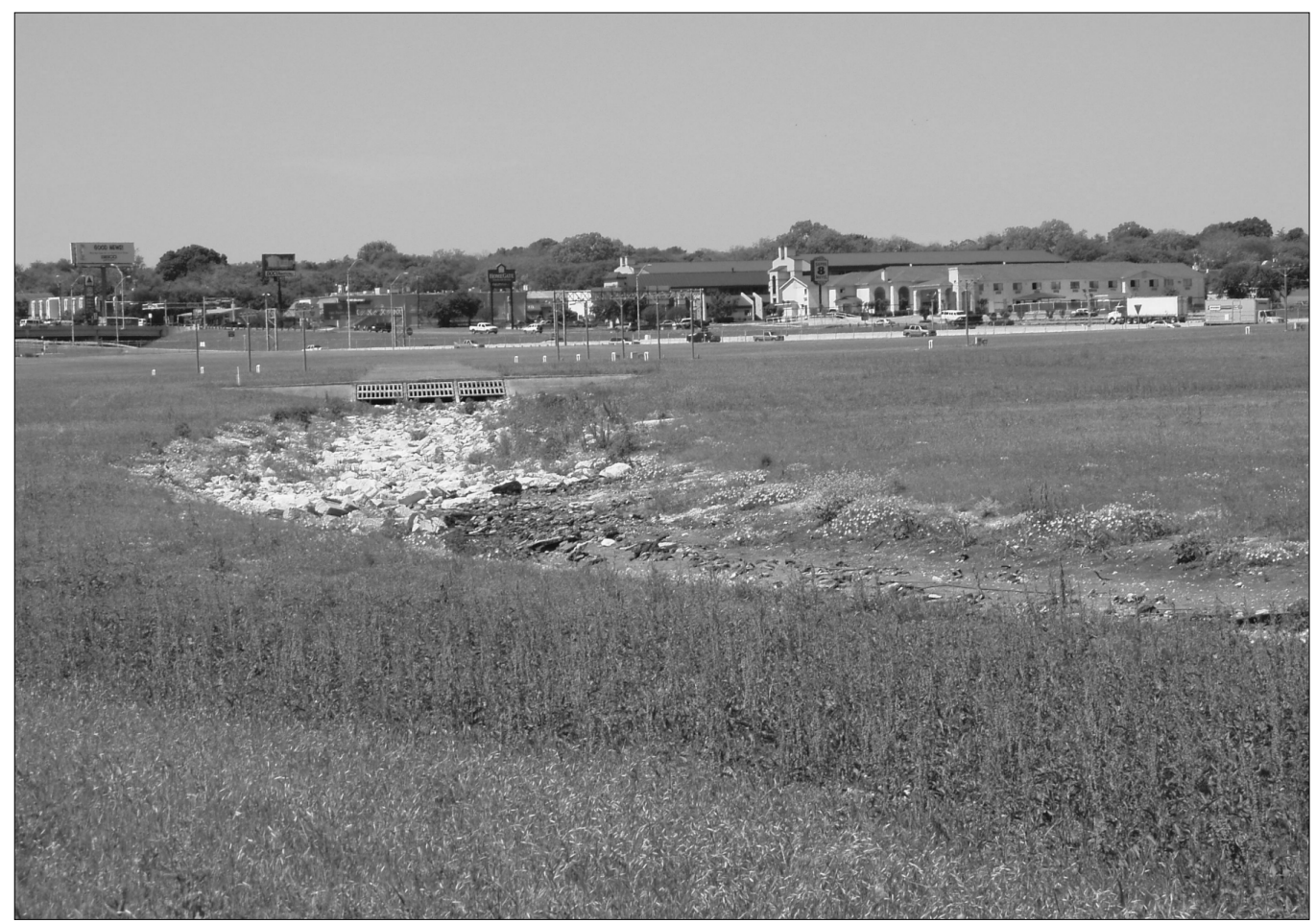

Figure 4-2. Drainage area in Tract 1. 
significantly reduced the probability of finding intact cultural deposits in the area. The northwestern portion of Tract 1, at the intersection of U.S. Highway 281 and JonesMaltsberger, also appears to have been heavily disturbed as indicated by the road base encountered in STs 53 and 54 . No artifacts were recovered from the shovel tests excavated in Tract 1 and no artifacts were noted on surface during the pedestrian survey.

\section{Tract 2}

Nineteen shovel tests (STs 80-98) and five backhoe trenches (BHTs 1-5) were excavated in Tract 2 in search of buried cultural materials (see Figure 3-2). The backhoe trenches were intended to inspect the portion of Tract 2 that was originally estimated to have a moderate probability for prehistoric sites. Two of the backhoe trenches (BHTs 1 and 2) were excavated on the north bank of Salado Creek, with the remaining three (BHTs 3-5) excavated along the south bank of the creek.

Three depositional zones were identified in BHT 1 (Figure 4-3). The A horizon consisted of fine to medium, well-sorted silty clay with moderate quantities of pebbles and gravels. Roots abounded in this horizon. The Bk horizon consisted of sandy silt with abundant pebbles and gravels throughout. The Bk1 horizon at the base of the trench consisted of wellsorted sandy silt with abundant medium to small gravels. The smaller size of the gravels may be indicative of lowerenergy transport than in the Bk horizon that contained many larger gravels and pebbles. A single chert flake was encountered at $62 \mathrm{cmbs}$ in the $\mathrm{Bk}$ horizon. This specimen, a secondary flake, appears to have been transported to this location as part of the stream bed load and exhibited numerous post-depositional flake scars along its edges. The large, hard-hammerstone flake was also heavily patinated.

BHT 2 was positioned roughly 25 meters north of BHT 1 to expose a portion of the Salado Creek floodplain. To our surprise, the entire trench contained trash deposits. It appears that this area of Tract 2 was the location of a landfill. Recent trash, in the form of bottles and other materials, was exposed immediately below the surface and a dense layer of trash and trash bags was exposed at a depth of roughly 1.0 meter below the surface (Figure 4-4).

Once it became evident that landfill debris may underlie parts of the north bank, backhoe trenching was halted on the north side of Salado Creek. While construction debris

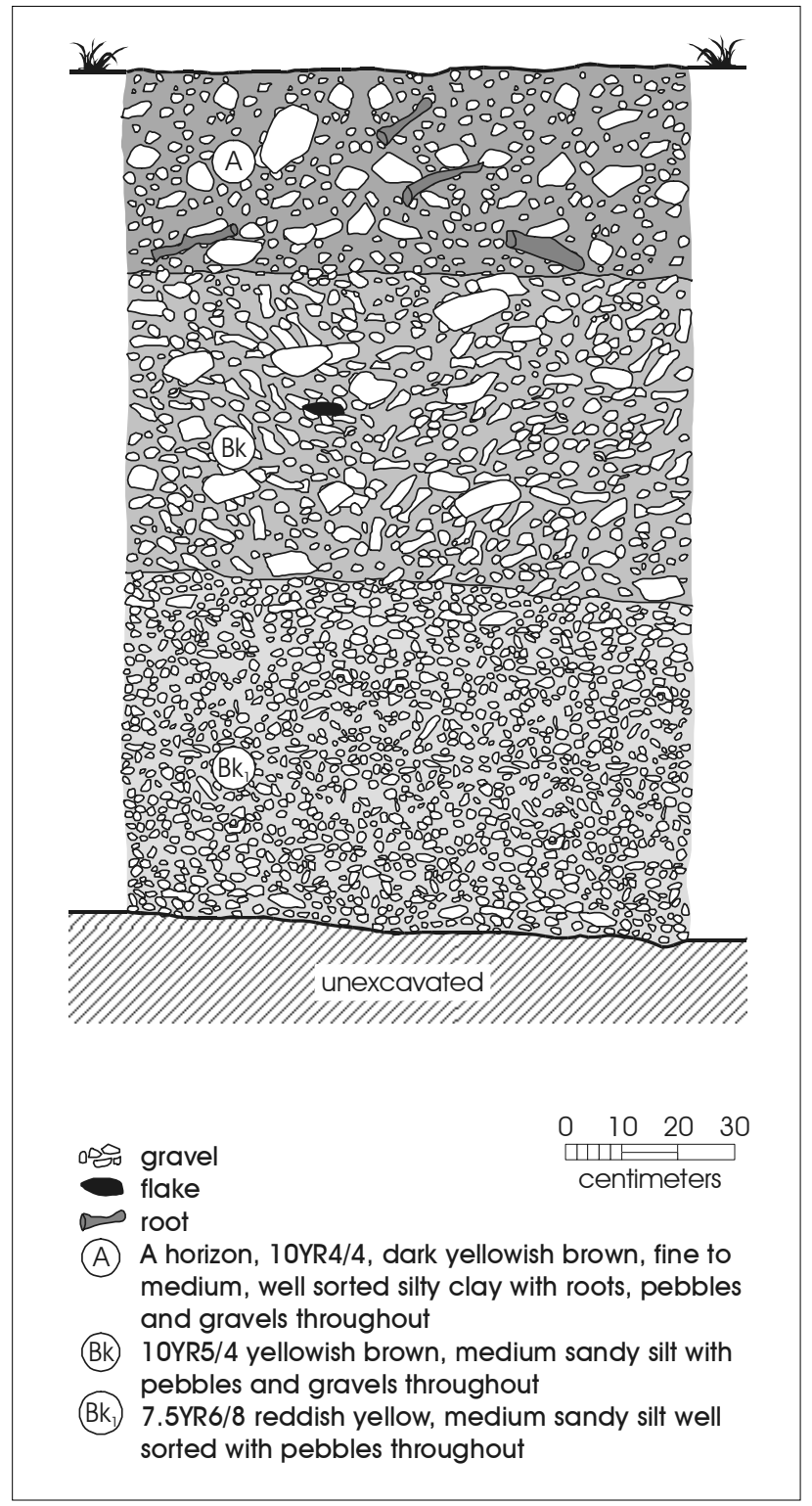

Figure 4-3. Profile of the east wall of Backhoe Trench 1.

was common along the southern bank of the creek (Figure 4-5), it was hoped that the terrace deposits may be less disturbed than on the north bank. BHT 3 was excavated near the western boundary of Tract 3. Seven depositional zones were identified in the trench. Disturbance was evident in the top $50 \mathrm{~cm}$ of the trench, as indicated by numerous fragments of rubber (Figure 4-6). While zones 5-7 appeared to be flood deposits of different load carrying capacities, they did not contain cultural materials. 


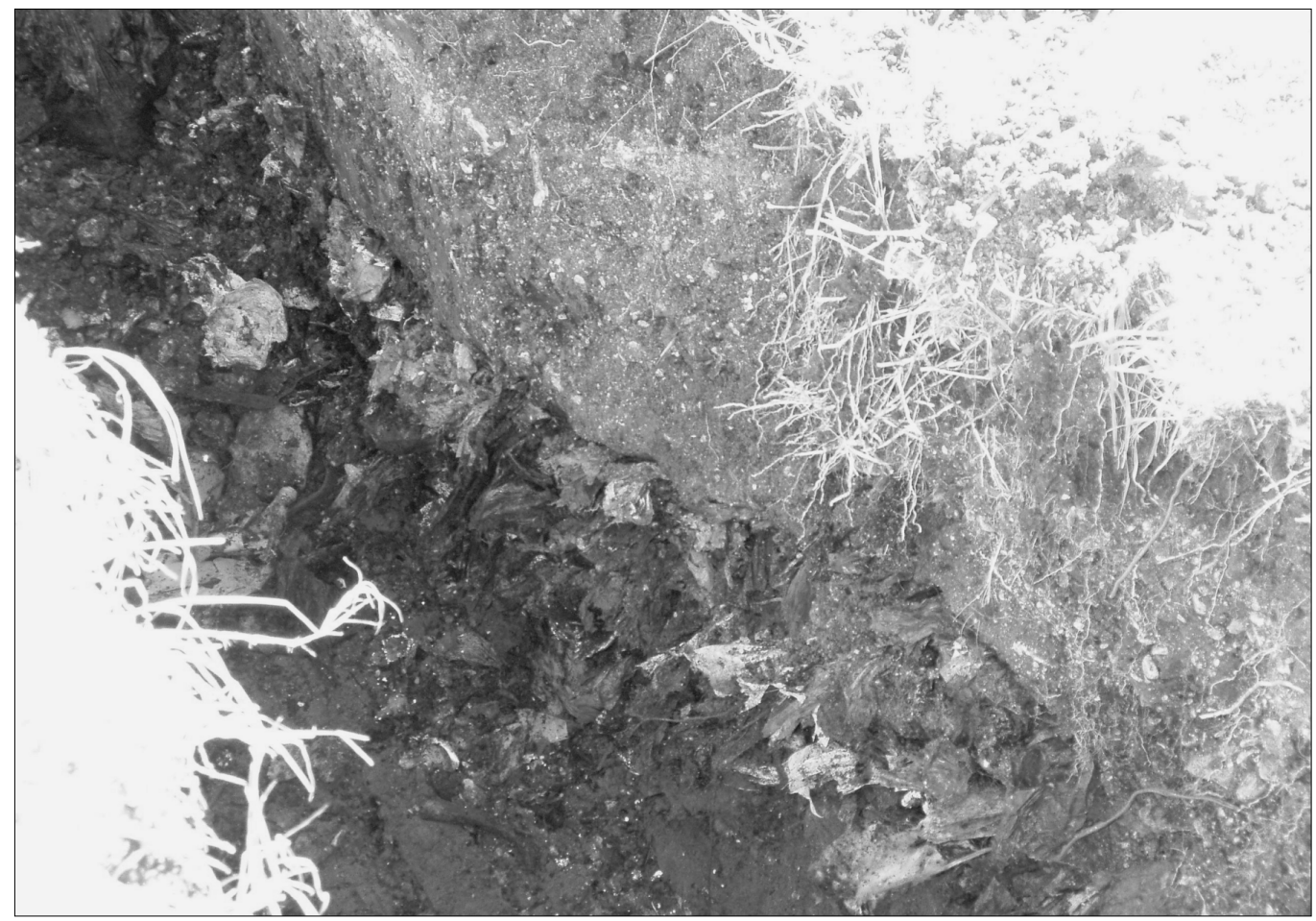

Figure 4-4. Landfill material encountered in Backhoe Trench 2.

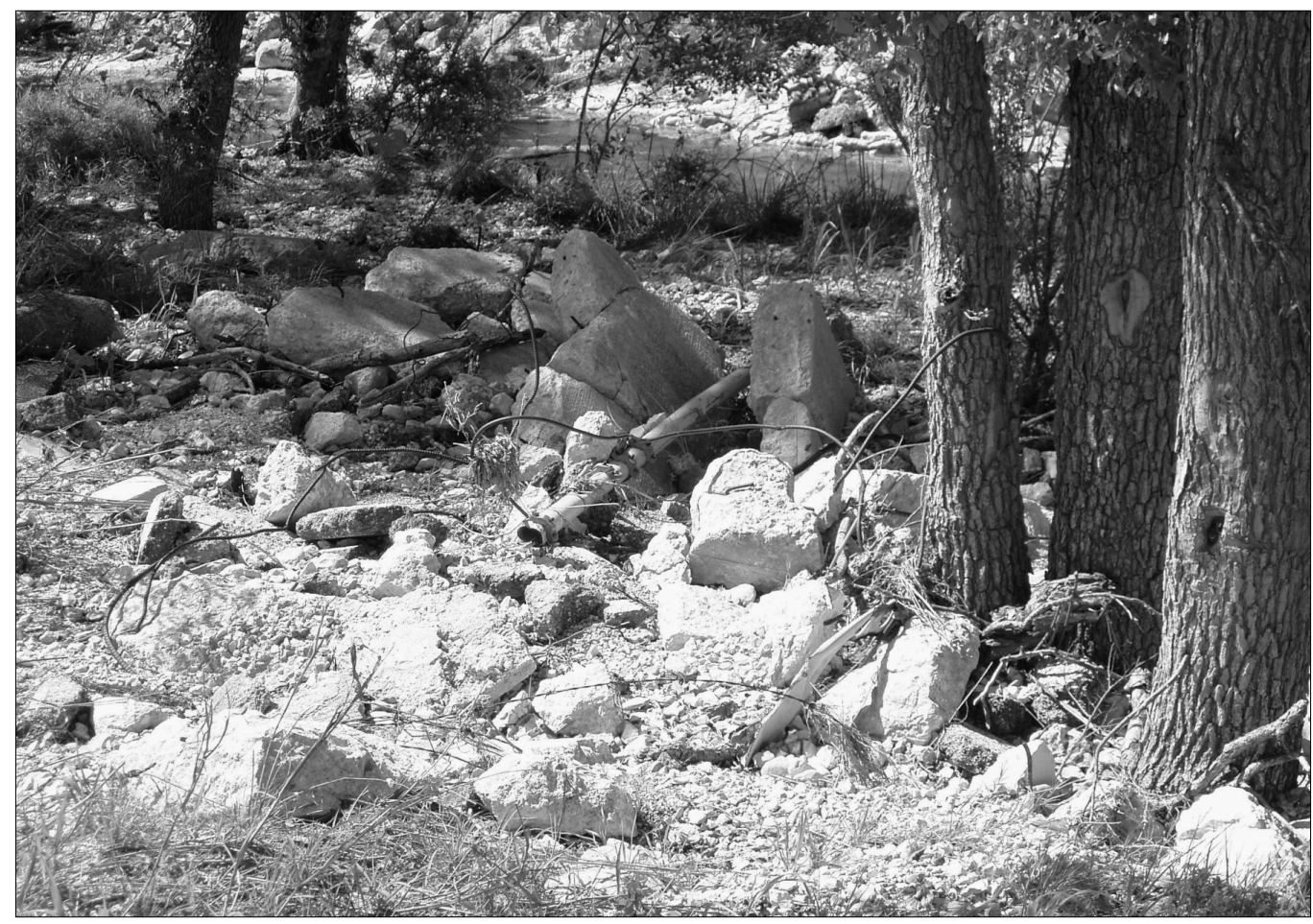

Figure 4-5. Debris on the south bank of Salado Creek in Tract 2. 
BHT 4 was excavated approximately 70 meters to the east of BHT 3. Three principal depositional strata were identified in the profile (Figure 4-7, Zones I, II and VIII). In addition, a number of silty clay lenses extend part way into the more massive gravel deposits of the trench. A single chert flake was encountered at nearly $90 \mathrm{~cm}$ below the surface within a silty clay matrix that had a high concentration of gravels and pebbles (Figure 4-7). Judging from the numerous micro-flake scars along it perimeter, the large secondary flake appears to have been river-transported to this location. In contrast to the flake found in BHT 1, this flake was not patinated.

BHT 5 was located east of BHT 4, it exhibited three soil horizons (Figure 4-8). The A horizon was a thin layer underlain by a thick clay horizon with moderate percentages of gravel. The basal horizon was a thick clay zone with small quantities of calcium carbonate nodules. No cultural material was recovered from this backhoe trench.

Although it was originally proposed that shovel tests would be excavated between the backhoe trenches, having seen the depth of the disturbances and the high-energy nature of the deposits, it was decided that no shovel tests would be excavated in the area.

In addition to the backhoe trenches, 19 shovel tests were excavated to search for buried cultural materials in the remaining low probability area of the tract located southsouthwest of Salado Creek. Given that this area fell within the high security zone of the airport, the archaeological crew was escorted by Mr. Kao Lin Chen during the survey.

The terminal depths and the deposits encountered by the 19 shovel tests are presented in Table 4-2. The artifacts recovered from the tests excavated within Tract 2 are presented in Table 4-3. Three shovel tests $(91,93$ and 94$)$ were excavated to the depth of $60 \mathrm{cmbs}$, while the remaining shovel tests were not excavated to this target terminal depth due to the presence of compacted road base at shallower depths.

The consistent presence of compact gravel road base in the extreme southwest portion of the tract near the existing runway suggests that surface preparation activities may have extended well northeast of the runway at the time of its construction (Figure 4-9). Additional subsurface disturbances may have been created by the construction of the paved road in the area (Figure 4-10). The presence of a compact gravel zone in STs 97 and 98 near the channel of Salado Creek may be connected to the construction of the

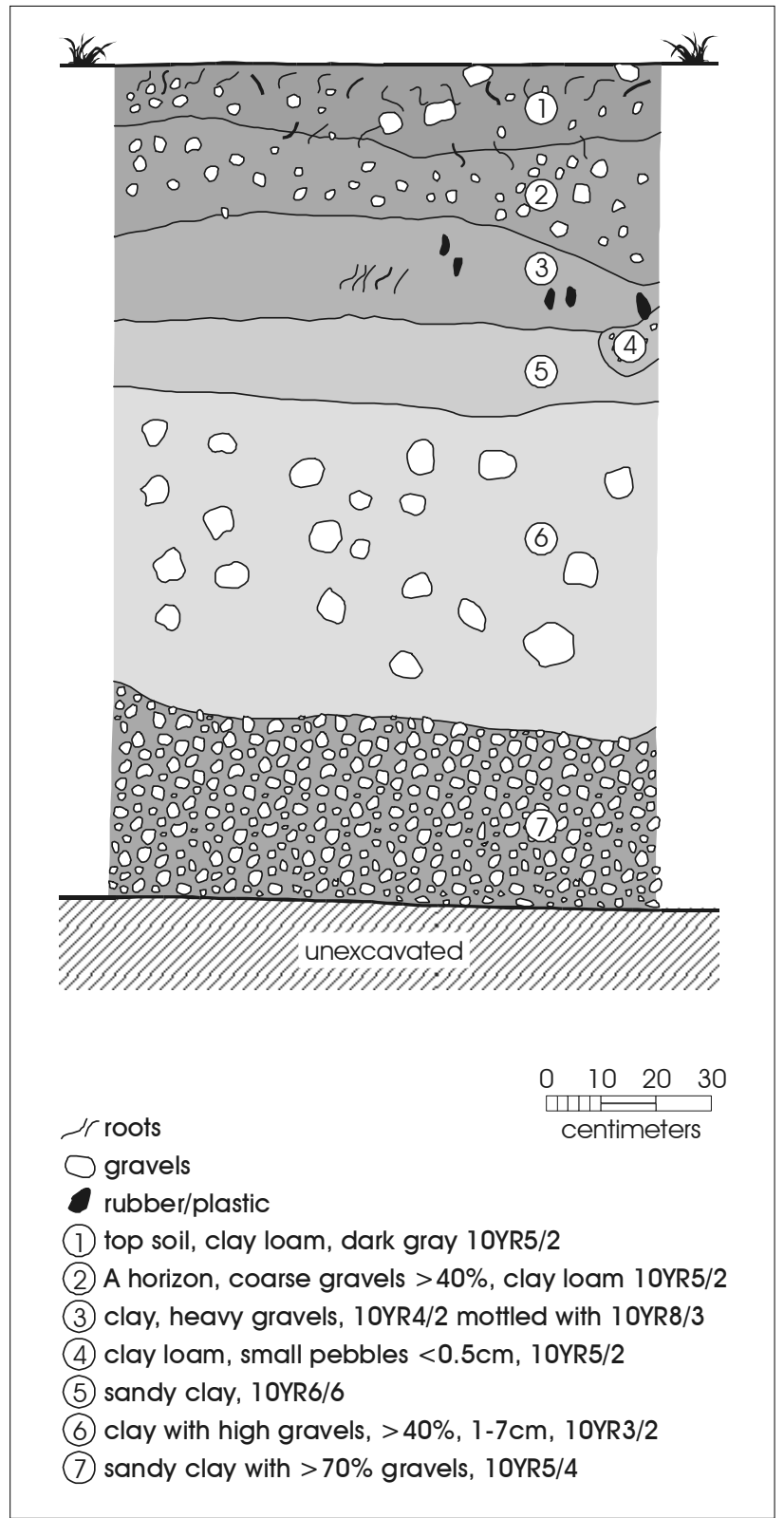

Figure 4-6. Profile of the east wall of Backhoe Trench 3.

perimeter road that runs east-west along the north fence in this area (see Figure 3-2).

Of the 19 shovel tests excavated in Tract 2, four (21\%; STs $83,87,88$ and 92 ) recovered cultural materials (Table 4-3). The materials were concentrated in Levels 1 and 2 (0-20 $\mathrm{cmbs})$ and consisted of flakes $(\mathrm{n}=3)$, one piece of recent 


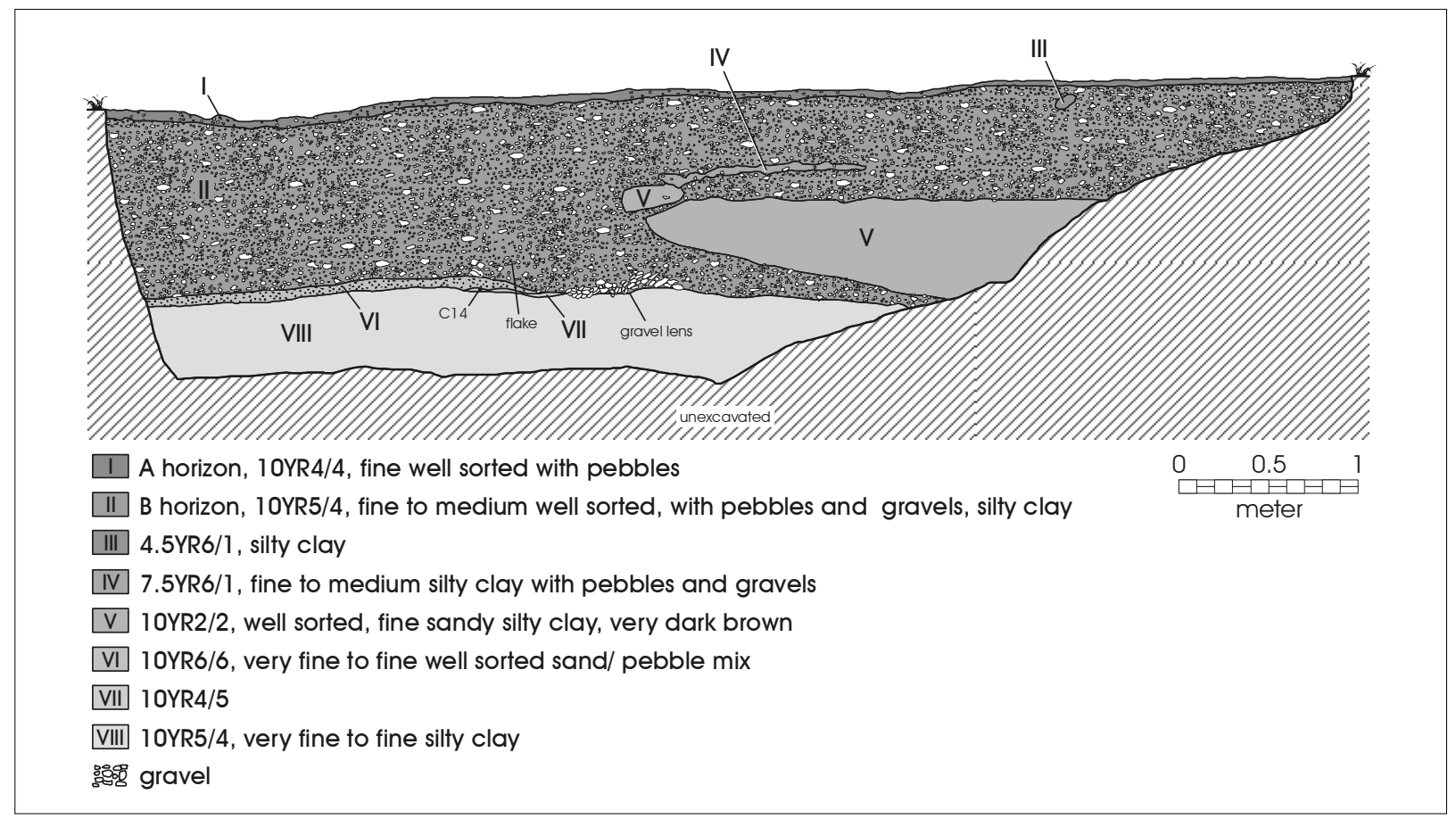

Figure 4-7. Profile of the east wall of Backhoe Trench 4.

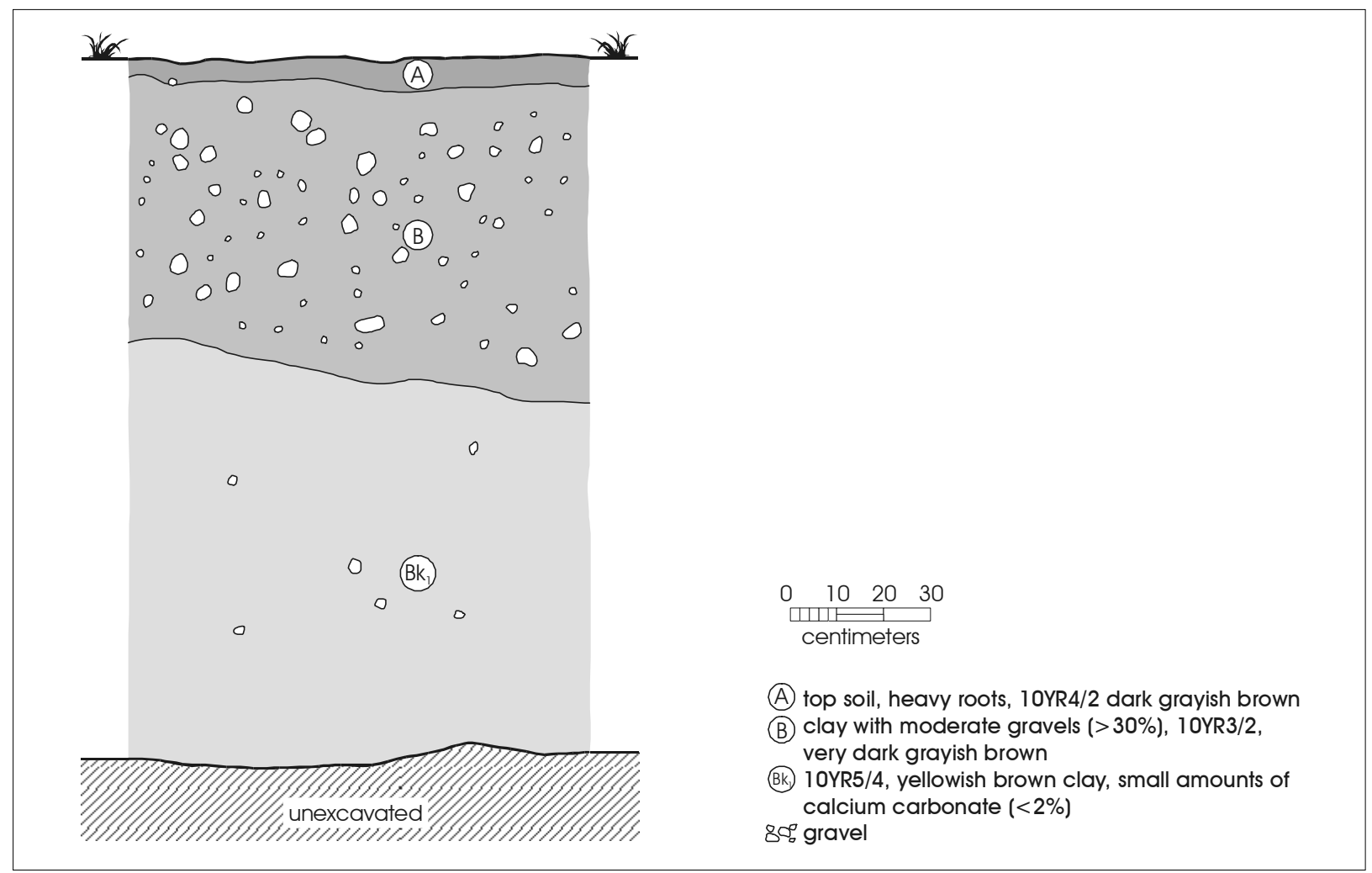

Figure 4-8. Profile of the east wall of Backhoe Trench 5. 
Survey for San Antonio International Airport Expansion

Table 4-2. Terminal Depths of Shovel Tests Excavated in Tract 2

\begin{tabular}{|c|c|c|}
\hline ST \# & Max. Depth (cmbs) & Disturbance \\
\hline 80 & 53 & road base \\
\hline 81 & 10 & road base \\
\hline 82 & 25 & road base \\
\hline 83 & 20 & compacted \\
\hline 84 & 30 & compacted \\
\hline 85 & 10 & road base \\
\hline 86 & 40 & road base \\
\hline 87 & 40 & road base \\
\hline 88 & 10 & road base \\
\hline 89 & 30 & road base \\
\hline 90 & 50 & gravel/compacted \\
\hline 91 & 60 & compacted \\
\hline 92 & 33 & max. depth \\
\hline 93 & 60 & road base \\
\hline 94 & 60 & max. depth \\
\hline 95 & 26 & max. depth \\
\hline 96 & 10 & gravel/compacted \\
\hline 97 & 10 & road base \\
\hline 98 & 30 & road base \\
\hline
\end{tabular}

glass (ST 87, Level 2), and a button (ST 88, Level 1). Because the shovel tests revealed that a majority of the area was disturbed, no additional tests were excavated in the vicinity of the positive units. The disturbances were noted both in the field and on the 1953 USGS topographic map of the area (see Figure 1-8) that shows an unimproved road leading from Wetmore Road to the southern portion of Tract 2. Structures are also depicted on this portion of Tract 2, adjacent to the unimproved road.

\section{Tract 3}

The original limits of Tract 3 included parcels on the east and west sides of the entrance road to McAllister Park. However, while CAR staff were surveying Tracts 1 and 2, and after Tract 3 was surveyed, the boundaries of Tract 3 were decreased to include only the parcel found east of the park road (see Figure 3-3). Therefore, this discussion only
Table 4-3. Artifacts Recovered from Shovel Tests in Tract 2

\begin{tabular}{|c|c|c|c|c|c|}
\hline ST/BHT & Level & Button & Debitage & Glass & Total \\
\hline ST 83 & 1 & & 1 & & 1 \\
\cline { 2 - 6 } & 2 & & 1 & & 1 \\
\hline ST 87 & 2 & & & 1 & 1 \\
\hline ST 88 & 1 & 1 & & & 1 \\
\hline ST 92 & 1 & & 1 & & 1 \\
\hline BHT 1 & $62 \mathrm{cmbs}$ & & 1 & & 1 \\
\hline BHT 4 & $90 \mathrm{cmbs}$ & & 1 & & 1 \\
\hline Total & & 1 & 5 & 1 & 7 \\
\hline
\end{tabular}

presents the results of the survey of the eastern section of the former tract. The results of the survey of the western section of the original tract are presented in Appendix A.

Twenty-one shovel tests were excavated in the eastern portion of Tract 3 (see Figure 3-3). Their terminal depths and the deposits they encountered are presented in Table 4-4. Contrary to the shovel testing results in Tracts 1 and 2 , the majority of the shovel tests in Tract 3 were excavated to the proposed terminal depth of $60 \mathrm{cmbs}$. Road base or asphalt were encountered in only three shovel tests $(14 \%$; STs 34, 35 and 38) in the vicinity of the park entrance road and the extreme northwest corner of the parcel. Shovel tests in the southern portion of Tract 3 contained a dense reddish brown silty clay matrix, while those in the northwestern portion were disturbed and one encountered bedrock at $5 \mathrm{cmbs}$.

Only two $(9.5 \%)$ of the tests were positive for cultural materials. Artifacts were recovered from Level 4 (30-40 cmbs) in ST 39 and Level $1(0-10 \mathrm{cmbs})$ in ST 61. They consisted a single piece of debitage (ST 39) and three pieces of recent glass (ST 61).

Although, the level of disturbance across the eastern portion of Tract 3 was less than in the other tracts, the area has been subject to clearing and contouring that have significantly altered its overall appearance and disturbed shallowly buried artifacts. In addition, the construction of a storage facility and the berm of soil that surrounds it in the extreme eastern corner of the property also documents extensive disturbances across specific portions of the tract. 


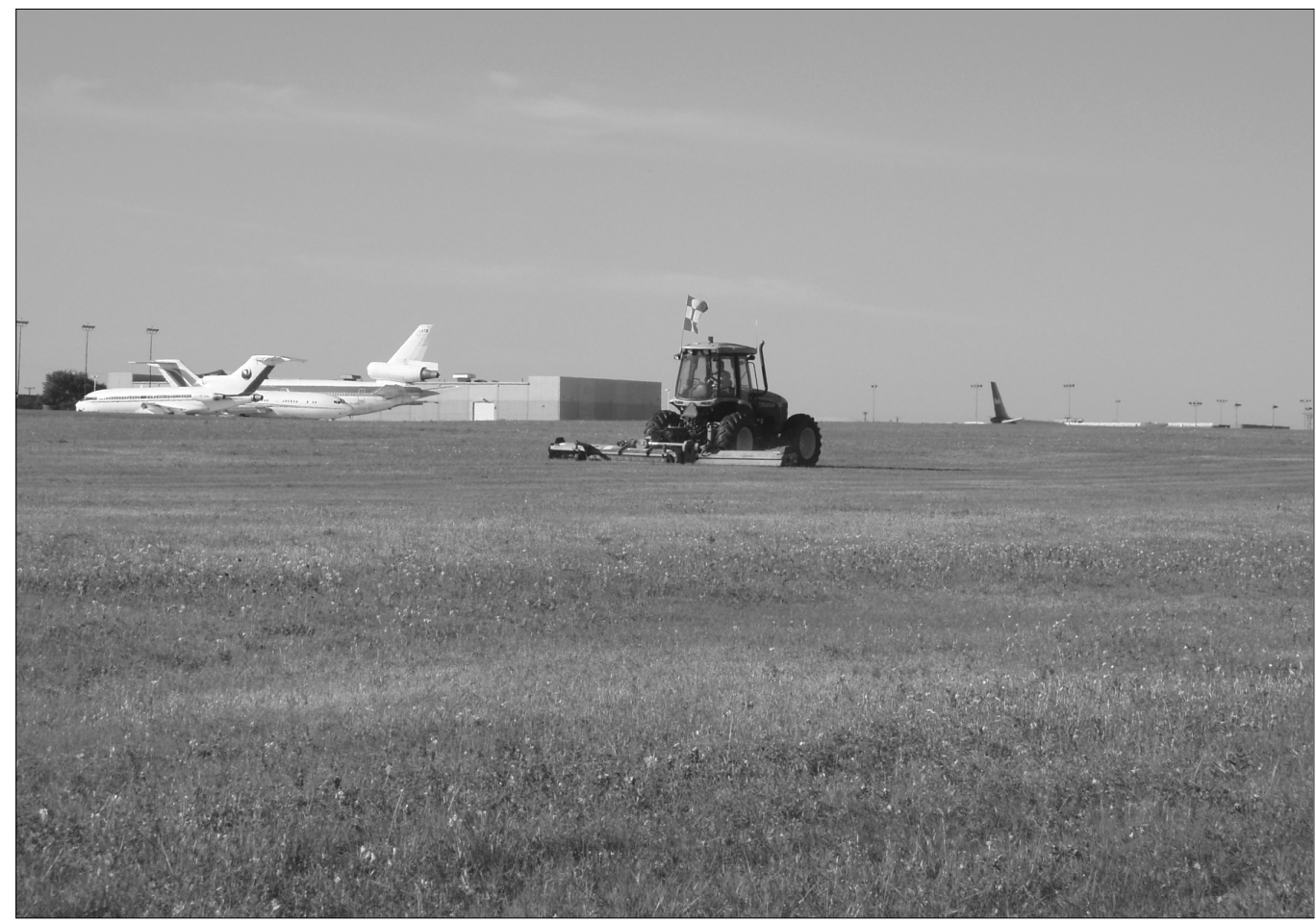

Figure 4-9. Southern portion of Tract 2.

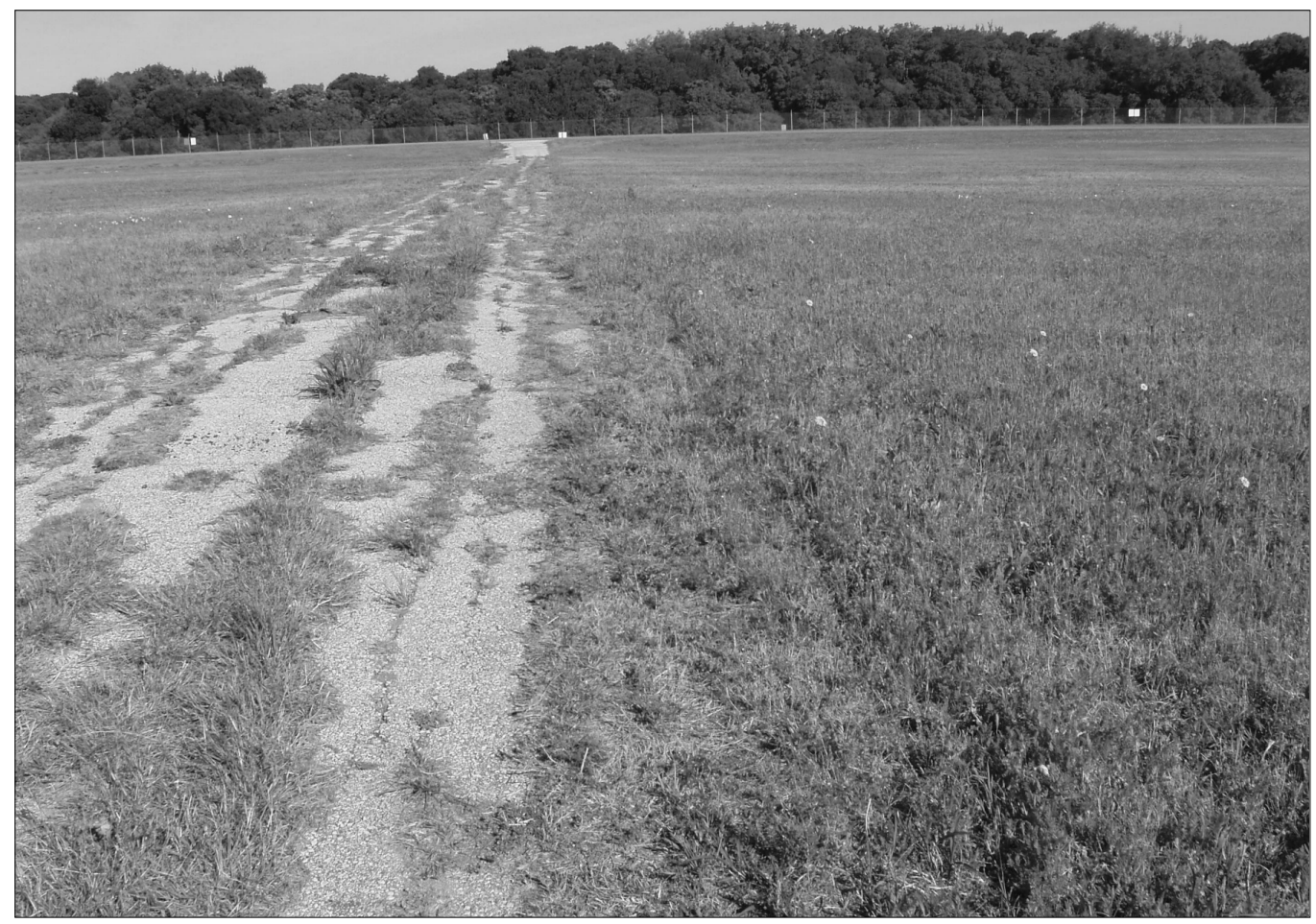

Figure 4-10. Paved roadway that crosses the southern portion of Tract 2. 
Table 4-4. Terminal Depths of Shovel Tests Excavated in Tract 3 (eastern section)

\begin{tabular}{|c|c|c|}
\hline ST \# & Max. Depth (cmbs) & Disturbance \\
\hline 34 & 60 & road base \\
\hline 35 & 60 & road base \\
\hline 36 & 60 & max. depth \\
\hline 37 & 5 & bedrock \\
\hline 38 & 50 & asphalt \\
\hline 39 & 60 & max. depth \\
\hline 40 & 50 & gravels (?) \\
\hline 41 & 60 & max. depth \\
\hline 42 & 60 & max. depth \\
\hline 57 & 60 & max. depth \\
\hline 58 & 60 & max. depth \\
\hline 59 & 60 & max. depth \\
\hline 60 & 60 & max. depth \\
\hline 61 & 60 & max. depth \\
\hline 62 & 60 & max. depth \\
\hline 63 & 60 & max. depth \\
\hline 64 & 60 & max. depth \\
\hline 65 & 60 & max. depth \\
\hline 66 & 60 & max. depth \\
\hline 67 & 60 & max. depth \\
\hline 68 & 60 & max. depth \\
\hline
\end{tabular}




\section{Chapter 5: Summary and Recommendations}

During the months of March and April 2005, the Center for Archaeological Research (CAR) conducted a 100 percent intensive pedestrian survey of three tracts of land measuring a combined total of 310 acres. The tracts, owned by the San Antonio Department of Aviation, have been designated for the planned expansion of the San Antonio International Airport. Adams Environmental, Inc., the firm responsible for the Environmental Impact Assessment associated with the planned project, contracted CAR to carry out the survey.

Two of the three tracts slated for development were associated with the expansion of existing runways. The two runway expansions will impact a 75 -acre area (Tract 1 ) and a 90.2-acre area (Tract 2). The third tract, measuring 145 acres, was to be the site of expansion-related developments. A few days after the completion of the survey, Adams Environmental, Inc. informed CAR that the western 100 acres of Tract 3 were not included in the project area. Therefore, the final size of Tract 3 that is part of this project measures only 45 acres. The resulting combined area to be impacted by the expansion and development activities, and therefore representing the Area of Potential Effect (APE), totaled 210.2 acres.

Prior to the initiation of the survey, the APE was divided into areas having moderate and low probabilities for encountering buried archaeological deposits. Areas that occurred within 30 meters of portions of an unnamed drainage and Salado Creek within Tracts 1 and 2, respectively, were identified as having moderate probabilities. All other areas were identified as having low probability for buried prehistoric sites. The banks of Salado Creek in Tract 2 were to be explored through backhoe trenching to search for buried deposits. The banks of the unnamed drainages in Tract 1 were to be intensively shovel tested for buried cultural remains. In addition, a revisit of site 41BX959 was to be completed in Tract 3. While the site was revisited and shovel tested, it was later determined that the site was located outside of the revised APE.

During a preliminary visit to the project area, and based on a subsequent comparison of the area with a 1953 USGS topographic map, CAR was able to establish that portions of the three tracts have been severely impacted during the past few decades. The impacted locations included those areas previously defined as having moderate probability for buried sites.

A total of 54 shovel tests and five backhoe trenches were excavated as part of the 100 percent intensive pedestrian survey of the APE. Fourteen shovel tests (STs 43-56) were excavated in Tract 1 . Of these, five (STs 49-52 and 54) were excavated in the moderate probability area along the larger of the two drainages crossing the tract. No prehistoric or historic cultural materials were recovered in the shovel tests. The majority of the shovel tests encountered highly compacted road base and/or asphalt consistent with the disturbed nature of the area as noted during the survey and based on the historic USGS quadrangle map.

Nineteen shovel tests (STs 80-98) and five backhoe trenches (BHTs 1-5) were excavated in Tract 2 in search of buried cultural materials. Backhoe Trenches 1 and 4 yielded a single flake each, recovered from $62 \mathrm{~cm}$ and $90 \mathrm{~cm}$ below surface, respectively. The trenching revealed that much of the northdescending bank of Salado Creek within Tract 2 was the site of a landfill and is severely disturbed. While two of the trenches in the south bank of the creek produced one flake each, these specimens appeared to have been part of the creek's bed load rather than having been deposited in situ.

Four of the 19 shovel tests excavated in Tract 2 (STs 83, 87, 88 and 92) recovered cultural materials. The materials were concentrated in the first two levels $(0-20 \mathrm{cmbs})$ and consisted of flakes $(\mathrm{n}=3)$ and recent artifacts (one piece of glass [ST 87, Level 2] and a button [ST 88, Level 1]). The findings from the shovel testing revealed that a majority of the area is disturbed and these findings are consistent with information derived from the 1953 USGS topographic map of the area.

The original limits of Tract 3 included parcels on the east and west sides of the entrance road to McAllister Park. During the survey, the boundaries of Tract 3 were decreased to include only the parcel found east of the park road. By this time, the entire 145-acre area had been surveyed. The results of the survey of the western section of the original tract, including the resurvey of site 41BX959, are presented in Appendix A. 
Twenty-one shovel tests were excavated in the eastern portion of Tract 3. Road base or asphalt were encountered in only three shovel tests (STs 34, 35, and 38) in the vicinity of the park entrance road and the extreme northwest corner of the parcel (see Figure 3-3). Shovel tests in the northern portion of the tract revealed disturbed deposits and one encountered shallowly buried bedrock. Two of the tests were positive for cultural materials, recovering a single piece of debitage (ST 39, Level 4) and three pieces of glass (ST 61, Level 1).

In summary, the pedestrian survey of the three tracts identified no surface cultural materials. The subsurface investigations using backhoe trenching and shovel testing produced few recent and prehistoric artifacts. These excavations, in combination with the review of the 1953 USGS quadrangle map, did however document significant disturbances to the deposits present within the three tracts. Given the low density of cultural deposits and their lack of associational integrity, it is suggested that these remains and the APE in general has very limited to no research potential. Therefore, additional archaeological investigations are not recommended within the APE and it is suggested that the project proceed as planned.

\section{Cultural Resources Assessment of the Widely Spaced Runway Option}

Following inception of the project, Mr. Lynn Kitchen of Adams Environmental, Inc. indicated that the Federal Aviation Administration is interested in evaluating an alternative location for the placement of runways rather than their extension. This option, called the Widely Spaced Runway Option, would position a series of runways immediately north of Tract 1 (Figure 5-1).

This option would impact roughly a 6,000 -foot portion of Salado Creek. A segment of the north-descending bank of Salado Creek in the proposed alternative area has been extensively impacted by a gravel quarry visible in Figure 5-1. In addition, portions of the south-descending bank of the creek have also been impacted by residential development (Figure 5-1). Even with these disturbed areas taken into consideration, this alternative location does include what would be considered high probability areas for finding buried prehistoric sites. As a result, a 100 percent intensive pedestrian survey of this area would be required prior to the inception of construction. The survey would have to rely on backhoe trenching as the primary method of site discovery, given the alluvial deposits present in this creek-proximate area. Based on the large number of sites found in other parts of the Salado Creek drainage, it is expected that some buried archaeological deposits will be present within the area contained in the Widely Spaced Runway Option.

In addition, several structures are visible on the aerial photograph of the area. Therefore, it is a possibility that any one of the structures may be 50 years or older. A historic structures survey also is recommended for this tract of land, including archival research and photo documentation of the structures. Archival research may encompass a property deed search, along with a search for any historic aerial photographs and/or maps of the tract of land. The findings of the archival research should be presented along with the results of the archaeological survey to the client and the Texas Historical Commission. 


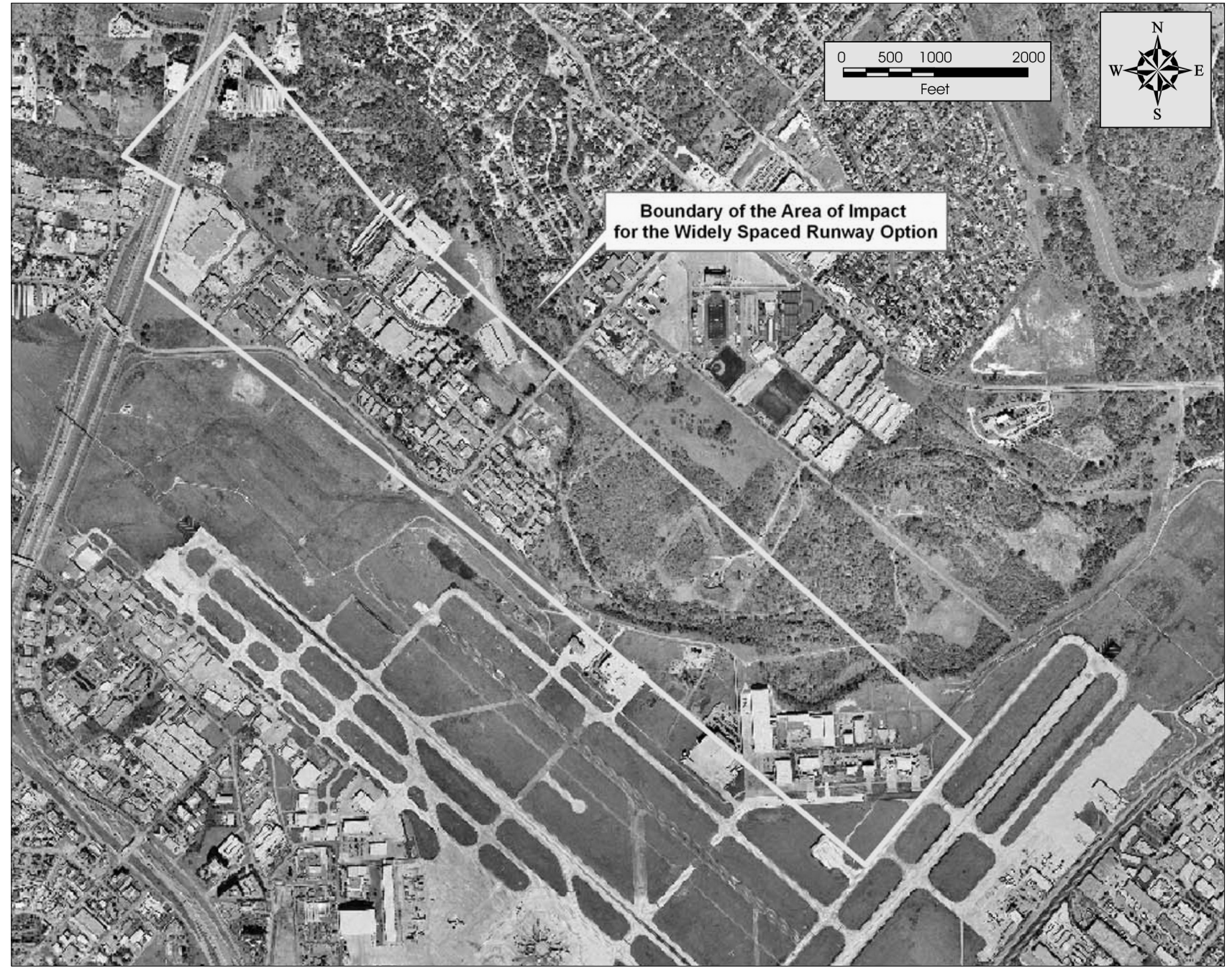

Figure 5-1. Boundary of the area of impact for the Widely Spaced Runway Option. 


\section{References Cited}

Black, S. L.

1989 South Texas Plains. In From the Gulf Coast to the Rio Grande: Human Adaptation in Central, South, and Lower Pecos Texas, by T. R. Hester, S. L. Black, B. W. Olive, A. A. Fox, K. Reinhart, and L. C. Bement, pp. 39-62. Research Series No. 33. Arkansas Archeological Survey, Fayetteville.

Black, S., and A. McGraw

1985 The Panther Springs Creek Site: Cultural Change and Continuity Within the Upper Salado Creek Watershed, South-Central Texas. Archaeological Survey Report, No. 100. Center for Archaeological Research, The University of Texas at San Antonio.

Fox, A. A.

1973 An Archeological Survey of the Northeast Preserve and J Street Park, San Antonio, Texas. Report submitted to the Texas Antiquities Committee.

1977 An Archaeological Assessment of the San Antonio 201 Wastewater Treatment Project. Archaeological Survey Report, No 41. Center for Archaeological Research, The University of Texas at San Antonio.

1979 Archaeological and Historical Investigations at 41BX180, Walker Ranch, San Antonio, Texas: Phase I. Archaeological Survey Report, No. 83. Center for Archaeological Research, The University of Texas at San Antonio.

Hester, T. R.

1995 The Prehistory of South Texas. Bulletin of the Texas Archeological Society 66:427-459.

Hester, T. R., F. A. Bass, A. A. Fox, T. R. Kelly, and M. F. Chadderdon

1974 Archaeological Survey of Areas Proposed for Modification in the Salado Creek Watershed, Bexar County, Texas. Archaeological Survey Report, No. 3. Center for Archaeological Research, The University of Texas at San Antonio.

Hudson, W. R., Jr., W. Lynn, and D. Scurlock

1974 Walker Ranch, An Archeological Reconnaissance and Excavations in Northern Bexar County, Texas. Office of the State Archeologist Reports No. 26. Texas Historical Commission, Austin.

Johnson, L. R., Jr.

1991 Early Archaic Life at the Sleeper Archeological Site, 41BC65, of the Texas Hill Country, Blanco County, Texas. Report No. 39. Texas State Department of Highways and Public Transportation, Austin.

Katz, P. R.

1987 Archaeological Mitigation at 41BX300, Salado Creek Watershed, South-Central Texas. Archaeological Survey Report, No. 130. Center for Archaeological Research, The University of Texas at San Antonio.

Lukowski, P. D.

1988 Archaeological Investigations at 41BX1, Bexar County, Texas. Archaeological Survey Report, No. 135. Center for Archaeological Research, The University of Texas at San Antonio.

Potter, D., and S. Black

1995 Archeology Along the Wurzbach Parkway: Module 2 Initial Testing and Evaluation of Five Prehistoric Sites in the Upper Salado Watershed, Bexar County, Texas. Studies in Archaeology 18. Texas Archeology Research Laboratory, The University of Texas at Austin. 
Scurlock, D, and W. R. Hudson, Jr.

1973 An Archeological Investigation of Walker Ranch. Texas Historical Commission.

Texas Historical Commission (THC)

2005 Texas Archeological Sites Atlas. <http://nueces.thc.state.tx.us/> Accessed March 2005.

Tomka, S.

2002 Data Recovery Excavations at 41BX1412: A Multicomponent Site in McAllister Park, San Antonio, Bexar County, Texas. Archaeological Survey Report, No. 324. Center for Archaeological Research, The University of Texas at San Antonio.

Tomka, S. A., T. K. Perttula, and R. J. Hard

1997 Archaeology of the Rio Grande and Central Coastal Plains, Texas: A Planning Document. Archaeological Survey Report, No. 266. Center for Archaeological Research, The University of Texas at San Antonio. Manuscript on file Center for Archaeological Research

Tomka, S., and R. C. Robinson

2000 The McAllister Park Roadway System Extension Project, San Antonio, Texas. Archaeological Survey Report, No. 301. Center for Archaeological Research, The University of Texas at San Antonio.

Zapata, J. E.

2002 McAllister Park Parking and Road Extension Project, San Antonio, Bexar County, Texas. Letter Report, No. 140. Center for Archaeological Research, The University of Texas at San Antonio. 


\section{Appendix A}

Intensive Pedestrian Survey of the Western Section of Tract 3 and Revisit of Site 41BX959 


\section{Appendix A: Intensive Pedestrian Survey of the Western Section of Tract 3 and Revisit of Site 41BX959}

During the pedestrian survey of Tract 3, and prior to CAR being informed that the western portion of the tract was no longer part of the project APE, CAR carried out a 100 percent survey of the area lying west of the McAllister Park entrance road (Figure A-1 [not published with report due to sensitivity of site location]). Site 41BX959, recorded in 1991, is located along the west-central portion of the area. The site was recorded as a north-south stretching oval encompassing roughly $19,200 \mathrm{~m}^{2}$. As part of the survey, CAR staff shovel tested the site to establish whether it warrants formal designation as a State Archeological Landmark and whether it is eligible for nomination to the National Register of Historic Places. This brief appendix describes the results of the survey of the 100-acre parcel and the revisit of 41BX959.

The site has been heavily disturbed by landscape modifications and clearing. Based on the surface and subsurface distribution of artifacts, the boundaries of the site were redefined to encompass a larger area than originally recorded. In addition, the presence of a number of historic artifacts (i.e., white earthenwares, bottle glass) and of a structure and a series of outbuildings on the 1953 USGS quadrangle led to the recognition of a historic component on site. The homestead is also shown on the 1932 historic Bracken 15 minute quadrangle sheet, indicating that the historic component dates to at least that period. Therefore, it is likely that the historic component dates to the early part of the twentieth century and perhaps as early as the later part of the nineteenth century.

Thirty-three shovel tests were excavated in the western portion of Tract 3. All but five of these (STs 29-33) were excavated to define the boundaries of 41BX959. The remaining five shovel tests were excavated in the extreme northwestern corner of the tract adjacent to the park road. Table A-1 presents the terminal depths of the shovel tests and the materials they encountered when they were terminated prior to the planned $60 \mathrm{~cm}$ below surface $(\mathrm{cmbs})$. Table A-2 lists the artifacts recovered from the shovel tests.
Seventeen $(60 \%)$ of the shovel tests excavated on 41BX959 produced cultural materials. Only one (ST 29) of the five shovel tests dug in the north corner of the tract was positive, yielding a single flake from Level $1(0-10 \mathrm{cmbs})$. The bulk $(63 \%)$ of the materials from the 17 positive shovel tests on 41BX959 came from Level 1 (0-10 cmbs). Artifact densities decreased with increasing depth (Level 2, $n=4$; Level 3, $n=5$; Level $4, n=2$ ). All but eight of the 30 artifacts are prehistoric specimens. Unmodified flakes $(\mathrm{n}=15)$ constitute 68 percent of the artifacts recovered from the shovel tests on site 41BX959. Three early to middle reduction stage bifaces were recovered as were two tested cobbles. A single Guadalupe adze proximal fragment was found in Level 1 $(0-10 \mathrm{cmbs})$ of ST 3. Guadalupe adzes are identified as diagnostic of the Early Archaic period (Black and McGraw 1985:146).

Given that the site is located on a small rise, the depositional context is not favorable for the rapid burial of cultural materials deposited on its surface. The bulk of the materials on site are found on surface and shallowly buried in Level 1 $(0-10 \mathrm{cmbs})$. Although other Early Archaic Guadalupe adzes have been recovered from the surface of the site (Steve Smith, CAR Staff, personal communication 2005), it is unlikely that the site contains only Early Archaic materials. The cores, early to middle reduction stage bifaces, and secondary hard-hammerstone flakes suggest that the principal activity carried out at the site was raw material procurement and early to middle stage reduction. No features were noted during the surface survey or identified as a result of the shovel testing.

Based on the primarily surface nature of the deposits, the probability that the artifact assemblage is a mix of temporal components, and the fact that no intact features have been identified on site, it is recommended that 41BX959 does not warrant formal designation as a State Archeological Landmarkand is not eligible for nomination to the National Register of Historic Places. 
Table A-1. Terminal Depths of Shovel Tests Excavated in the Western Section of Tract 3 (outside revised project area)

\begin{tabular}{|c|c|c|}
\hline ST \# & Max. Depth (cmbs) & Disturbance \\
\hline 1 & 30 & cobbles \\
\hline 2 & 40 & cobbles \\
\hline 3 & 30 & cobbles \\
\hline 4 & 30 & caliche/cobbles \\
\hline 5 & 60 & max. depth \\
\hline 6 & 60 & max. depth \\
\hline 7 & 50 & cobbles \\
\hline 8 & 30 & bedrock \\
\hline 9 & 30 & bedrock \\
\hline 10 & 30 & bedrock \\
\hline 11 & 60 & max. depth \\
\hline 12 & 60 & max. depth \\
\hline 13 & 60 & max. depth \\
\hline 14 & 60 & max. depth \\
\hline 15 & 60 & max. depth \\
\hline 16 & 40 & cobbles \\
\hline 17 & 40 & cobbles \\
\hline 18 & 55 & cobbles \\
\hline 19 & 60 & max. depth \\
\hline 20 & 60 & max. depth \\
\hline 21 & 60 & max. depth \\
\hline 22 & 60 & max. depth \\
\hline 23 & 51 & bedrock \\
\hline 24 & 42 & bedrock \\
\hline 25 & 60 & max. depth \\
\hline 26 & 47 & bedrock \\
\hline 27 & 46 & bedrock \\
\hline 28 & 30 & pipe \\
\hline 29 & 30 & bedrock \\
\hline 30 & 46 & bedrock \\
\hline 31 & 60 & max. depth \\
\hline 32 & 46 & cobbles \\
\hline 33 & 50 & bedrock \\
\hline
\end{tabular}


Table A-2. Artifacts Recovered from Shovel Tests in the Western Section of Tract 3 (outside revised project area)

\begin{tabular}{|c|c|c|c|c|c|c|c|c|c|c|c|c|c|}
\hline ST \# & Level & 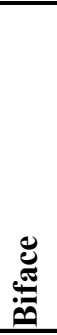 & 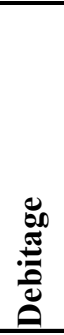 & 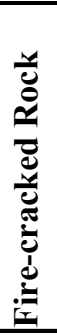 & $\frac{\omega}{\tilde{U}}$ & 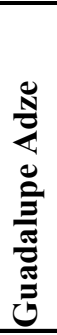 & 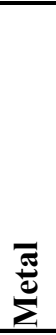 & 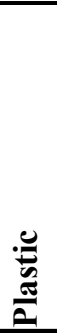 & 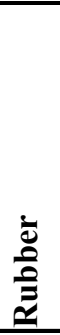 & $\begin{array}{l}\frac{0}{0} \\
0 \\
0 \\
0 \\
0 \\
0 \\
0 \\
0\end{array}$ & $\begin{array}{l}\stackrel{\mathscr{J}}{\leftrightarrows} \\
:\end{array}$ & 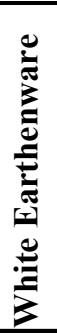 & $\frac{n}{\tilde{E}}$ \\
\hline 1 & 1 & & 1 & & & & & & & & & & 1 \\
\hline 2 & 1 & & 1 & & & & & & & & & & 1 \\
\hline 3 & 1 & & & & & 1 & & & & & & & 1 \\
\hline 5 & 1 & 1 & 2 & & & & & & & & & & 3 \\
\hline 7 & 3 & & 1 & & & & & & & 2 & & & 3 \\
\hline \multirow[t]{2}{*}{8} & 1 & 1 & & & & & & & & & 1 & & 2 \\
\hline & 2 & & 1 & & & & & & & & & & 1 \\
\hline 9 & 2 & & 1 & & & & & & & & & & 1 \\
\hline 13 & 1 & & 1 & & & & & & & & & & 1 \\
\hline 17 & 1 & & 1 & & & & & & & & & & 1 \\
\hline 18 & 1 & $x$ & & & & & & & & & & 1 & 1 \\
\hline 19 & 4 & & 1 & & & & & & & & & & 1 \\
\hline \multirow[t]{2}{*}{20} & 1 & 1 & & & & & & & & & & & 1 \\
\hline & 3 & & 1 & & & & & & & & & & 1 \\
\hline 22 & 1 & & 1 & & & & & & & & & & 1 \\
\hline \multirow[t]{4}{*}{23} & 1 & & & & & & 2 & & & & & & 2 \\
\hline & 2 & & 1 & & & & & & & & & 1 & 2 \\
\hline & 3 & & & 1 & & & & & & & & & 1 \\
\hline & 4 & & 1 & & & & & & & & & & 1 \\
\hline 24 & 1 & & & & & & & & 1 & & & & 1 \\
\hline 27 & 1 & & & & & & & 1 & & & & & 1 \\
\hline 28 & 1 & & & & 1 & & & 1 & & & & & 2 \\
\hline 29 & 1 & & 1 & & & & & & & & & & 1 \\
\hline Totals & & 3 & 15 & 1 & 1 & 1 & 2 & 2 & 1 & 2 & 1 & 2 & 31 \\
\hline
\end{tabular}




\section{References Cited}

Black, S., and A. McGraw

1985 The Panther Springs Creek Site: Cultural Change and Continuity Within the Upper Salado Creek Watershed, South-Central Texas. Archaeological Survey Report, No. 100. Center for Archaeological Research, The University of Texas at San Antonio. 
